NUREG/CR-1645

DPST-NUREG-80-1

\title{
THE PWR LOSS-OF-COOLANT ACCIDENT ANALYSIS CAPABILITY OF THE WRAP-EM SYSTEM
}

M. V. GREGORY

F. BERANEK
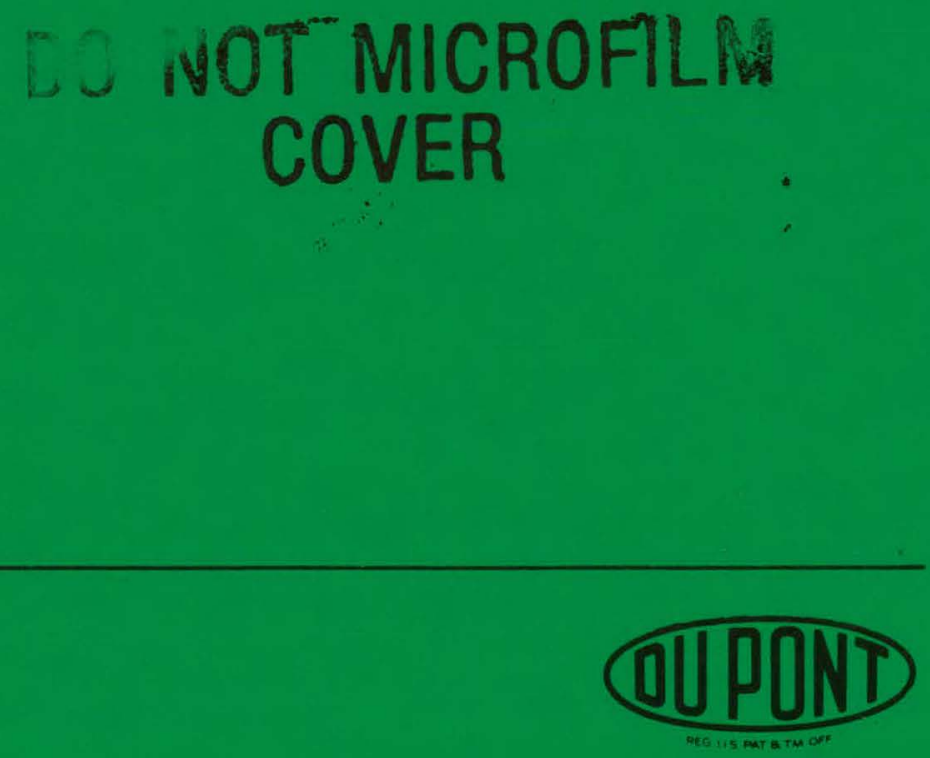

E. I. du Pont de Nemours \& Co. Savannah River Laboratory

Aiken, SC 29808 


\section{DISCLAIMER}

This report was prepared as an account of work sponsored by an agency of the United States Government. Neither the United States Government nor any agency Thereof, nor any of their employees, makes any warranty, express or implied, or assumes any legal liability or responsibility for the accuracy, completeness, or usefulness of any information, apparatus, product, or process disclosed, or represents that its use would not infringe privately owned rights. Reference herein to any specific commercial product, process, or service by trade name, trademark, manufacturer, or otherwise does not necessarily constitute or imply its endorsement, recommendation, or favoring by the United States Government or any agency thereof. The views and opinions of authors expressed herein do not necessarily state or reflect those of the United States Government or any agency thereof. 


\section{DISCLAIMER}

Portions of this document may be illegible in electronic image products. Images are produced from the best available original document. 


\section{DISCLAIMER}

This report was prepared by E. I. du Pont de Nemours and Company (Du Pont) for the United States Department of Energy under Contract DE-AC09-76SR00001 and is an account of work performed under that Contract. Neither the United States, the United States Department of Energy nor Du Pont, nor any of their employees, makes any warranty, express or implied, or assumes any legal liability or responsibility for the accuracy, completeness, or usefulness of any information, apparatus, product, or process disclosed herein, or represents that its use will not infringe privately owned rights. Reference herein to any specific commerical product, process, or service by trade name, mark, manufacturer, or otherwise does not necessarily constitute or imply endorsement, recommendation, or favoring of same by Du Pont or by the United States Government or any agency thereof. The views and opinions of authors expressed herein do not necessarily state or reflect those of the United States Government or any agency thereof. 
THE PWR LOSS-OF-COOLANT ACCIDENT ANALYSIS CAPABILITY OF THE WRAP-EM SYSTEM

by

M. V. GREGORY

F. BERANEK

Approved by:

M. M. Anderson, Jr., Research Manager

Nuclear Physics Division

Date Published: August 1980
NUREG/CR--1645

TI85 015957

Savannah River Laboratory

Aiken, SC 29808

Operated by

E. I. du Pont de Nemours \& Co.

for the U.S. Department of Energy

under lontract No. DE-AC09-76SR00001

Prepared for:

Division of Reactor Safety Research

U.S. Nuclear Regulatory Commission

Washington, DS, 20555

Under Interagency Agreement DOE

NRC FTN Nn, R-4126-B

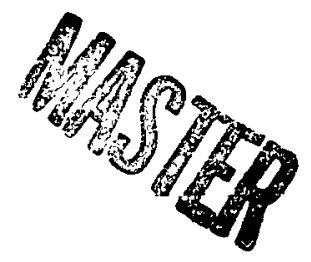

\section{E. I. du Pont de Nemours \& Co. Savannah River Laboratory Aiken, SC 29808}

PREPARED FOR THE U. S. DEPARTMENT OF ENERGY UNDER CONTRACT DE-AC09.76SRO0001 


\section{ABSTRACT}

The modular computational system known as the Water Reactor Analysis Package (WRAP) has been extended to provide the computational tools required to perform a complete analysis of loss-ofcoolant accidents (LOCAs) in pressurized water reactors (PWR). The new system is known as the WRAP-EM (Evaluation Model) system and. will be used by NRC to interpret and evaluate reactor vendor EM methods and computed results.

The system for PWR-EM analysis is comprised of several computer codes which have been developed to analyze a particular. phase of a LOCA. These codes include GAPCON for calculation of initial fuel conditions, WRAP (the previously developed SRL analog of. RELAP4/MOD5) for analysis of the system blowdown and refill, the FLOOD option in WRAP for analysis of the reflood phase, and FRAP for the calculation of the behavior of the hot fuel pin. In addition, a PWR steady-state initialization procedure has been developed to provide the initial operating state of the reactor system. The PWR-EM system is operational and is being evaluated. to determine the adequacy and consistency of the physical models employed for EM analysis.

\section{DISCLAIMER}

This report was prepared as an account of work sponsored by an agency of the United States Government. Neither the United States Government nor any agency thereof, nor any of their employees, makes any warranty, express or implied, or assumes any legal liability or responsibility for the accuracy, completeness, or usefulness of any information, apparatus, product, or process disclosed, or represents that its use would not infringe privately owned rights. Reference herein to any specific commercial product, process, or service by trade name, trademark, manufacturer, or otherwise does not necessarily constitute or imply its endorsement, recommendation, or favoring by the United States Government or any agency thereof. The views and opinions of authors expressed herein do not necessarily state or reflect those of the United States Government or any agency thereof. 
1.0 Introduction 7

2.0 Summary 8

3.0 System Overview 9

4.0 New WRAP-EM Computational Capabilities 11

4.1 EM Modifications to WRAP Blowdown Capability 11

4.2 Initial Fuel Condition Calculation 13

4.3 Fuel Hot Pin Analysis 13

4.4 Refill Analysis 15

4.5 Reflood Analysis 15

4.6 PWR Steady-State Procedure 18

5.0 Modular Interfaces for Data Transfer 19

5.1 GAPCON/WRAP 19

5.2 GAPCON/FRAP 21

5.3 WRAP/FRAP 21

5.4 WRAP/REFILL-FLOOD 22

5.5 FLOOD/FRAP 22

6.0 Zion Test Problem 22

6.1 Blowdown Nodalization 23

6.2 Reflood Nodalization 23

6.3 Computational Steps 23

6.4 Results 27

6.4 .1 TWRAM 29

6.4 .2 FI. 6 N 35

6.4.3 FRAP 35

6.4.3.1 Clad Surface Temperature $\quad 39$

6.4.3.2 Fuel Pin Rupture 39

6.4.4 Computer Time and Storage 39.

7.0 WRAP-EM Availability and Installation Requirements 39

8.0 References 43 


\section{List of Figures}

1 Overall St ructure of WRAP-PWR-EM System. 10

2 PWR Analysis Scheme 12

3 Modular Interfaces 20

4 System Nodalization Diagram for Zion Blowdown Model 24

5 Heat Slab Nodalization Diagram for Zion Blowdown Model 25

6 Nodalization Diagram for Zion Reflood Model ' 26

7 Hot Channel Core Inlet Flow (Junction.41) 30

8 Core Average Quality (Volume 42) 31

9 Slab Surface Temperature (S1ab 15) .32

10 Upper Plenum Pressure (Volume 54) 33

11 Cold Leg Break Flow (Junction 25), 34

12 Core Inlet Flow During Reflood 36

13 Core Mixture Level During Reflood. 37

14 Hottest Slab Surface Temperature During Reflood 38

15 Clad Surface Temperature at 8.4 Ft 40

16 Hoop Strain at $6.0 \mathrm{Ft} .41$

\section{List of Tables}

1 GAPCON Input Options for WRAP-EM St udies 14 .

2 Initial States 28

3 Computer Requirements 42 
The Idaho National Engineering Laboratory (INEL) provided key support during the development and checkout of the PWR LOCA analysis capability of the WRAP-EM system. The efforts of the members of the staff at INEL are gratefully acknowledged. In addition to the authors, several other individuals in the Savannah River Laboratory contributed to the development of WRAP-PWR-EM. Their names are listed below, and their contributions are gratefully acknowledged.
P. L. Ames
M. M. Anderson
$R$. R. Beckmeyer
J. R. Bryce
M. R. Buckner
N. H. Kuehn

P. B. Parks

R. L. Reed

D. A. Sharp

R. N. Sims

W. F. Winn 
Previous Documents in Series

DPST-NUREG-77-1 (June 1977)

DPST-NUREG-77-2 (June 1977)

DPST-NUREG-77-3 (June 1977)

DPST-NUREG-78-1 (April 1979)

DPST-NUREG-78-2 · (April 1979).

DPST-NÚREG-78-3 (April 1979) 


\subsection{INTRONUCTION}

WRAP-EM (Water Reactor Analysis Package-Fvaluation Model) is a modular system of computer codes which provides the computational tools required to perform a complete analysis of postulated loss-of-coolant accidents (LOCAs) in light water nuclear power reactors. The system is being developed at the Savannah River Laboratory (SRL) for use primarily by the Nuclear Regulatory Commission (NRC) to interpret and evaluate reactor vendor evaluation model (EM) ${ }^{l}$ methods and computed results. The capability of the WRAP-EM system for analysis of pressurized water reactors (PWRs) is described in this report. A similar analysis capability for boiling water reactors (BWRs) is described in Reference 2. A second phase in the development of each of these capabilities has involved an evaluation of the adequacy and consistency of the physical models employed in each computational step for EM analyses. That work is described in References 3 and 4. Future work will be directed toward a series of reference calculations for both PWRs and BWRs. Modifications and improvements will be incorporated into the system as a result of these studies to provide a system capable of analyzing a broad range of LOCAs, i.e., large and small breaks in a variety of locations in the reactor system.

The WRAP-EM system is a major extension of the WRAP 5,6 system developed at SRL during 1977.* WRAP is a modified version of the RELAP 4 code ${ }^{* *}$ with an extensively restructured input format, a . dynamic dimensioning capability, and additional computational capabilities such as an automatic steady-state option and an automatic restart capability with provision for renodalization. The initial objective in the development of WRAP was to provide a. user-oriented system for routine production use that was more efficient and amendable to modification than the then-existing RELAP 4 code. In accomplishing this objective, the following tasks were completed:

- Development of an improved format for user input.

- Development of automatic steady-state initialization procedures for pressurized and boiling water reactors.

- Development of an automatic spatial renodalization procedure.

- Implementation of a dynamic dimensioning capability.

\footnotetext{
\# In the preparation of this document, a basic familiarity of the reader with the concepts presented in References 5 and 6 was assumed.

** RELAP4/MOD5/UPDATE? - latest released version when WRAP project began in 1976.'
} 
- FORTRAN cleanup, FORTRAN commenting, and generation of comprehensive programming documentation.

- Implementation of WRAP under the JOSHUA ${ }^{8}$ operating system in a modular form.

The modular structure of the WRAP system has been extended to provide all the computational capabilities required to audit EM analyses of LOCAs in pressurized water reactors. These capabilities include:

- Calculation of the initial fuel condition.

- Calculation of the initial thermal-hydraulic state of the reactor system.

- Calculation of the blowdown phase of the LOrA.

- Calculation of the refill phase of the J.OCA.

- Calculation of the reflood phase of the LOCA.

- Calculation of the peak clad temperature of the hottest pin in the core.

In the remainder of this report, an overview of the PWR capability of the WRAP-EM system will be presented. Princinally, the report will describe the modular structure of the WRAP-EM system and the data interfaces for transfer between the various computational steps. Appropriate references for the documentation of the physical models used in the computer codes incorporated in the WRAP-EM system are included in the references. Companion reports ${ }^{9}, 10$ describe the PWR steady-state procedure developed at SRL and the additional input required for the new computational capabilities of the WRAP-EM s.ystem.

\subsection{SUMMARY}

The WRAP-EM system provides the computational tools required to analyze all phases of the LOCA in pressurized and boiling water reactors. WRAP-EM provides an EM description of the reactor system and will be used by NRC in the evaluation of current 1 icensing concerns, and in the development of reference calculations and sensitivity studies used to evaluate vendor EM methods and computed. results. The system for PWR-EM analysis is comprised of several computer codes, each of which has been developed to analyze a particular phase of a LOCA. These codes include GAPCON 11 for 
calculation of initial fuel conditions, WRAP (the previously developed SRL analog of RELAP4/MOD5) for analysis of the system blowdown and refill, FLOOD ${ }^{7}$ for analysis of the reflood phase, and FRAP 12 for analysis of the hot pin. In addition, a PWR steadystate initialization procedure ${ }^{9}$ has been developed to provide the initial operating state of the reactor system.

WRAP-EM is designed to operate under the JOSHUA operating system ${ }^{8}$ which was developed at SRL in 1968 and 1969 and has been in production use since 1970, JOSHUA provides extensive data management facilities and user conveniences for problem setup and execution through the JOSHUA CRT terminal system. For computers without terminal facilities, a JOSHUA Terminal Simulator ${ }^{6}$ has been developed to simulate JOSHUA operations in the batch mode with card input.

The data management facilities of the JOSHUA system are used to provide automatic transfer of data between all computational steps. The use of a modular structure and standardized data base minimizes the amount of human intervention required in a complete LOCA analysis and provides for simplified maintenance and incorporation of new modules in the system.

\subsection{SYSTEM OVERVIEW}

The overall structure of the WRAP-EM system is shown in Figure 1. Initial fuel conditions are calculated as a function of burnup by the GAPCON ${ }^{1}$ module. Selected parameters are passed to FRAP ${ }^{2}$ and WRAPIT, the generalized input processor, for initialization of the transient fuel models. GAPCON results are also stored on magnetic tape or disk for use in subsequent calculations. The steady-state initialization procedure (both PWR $^{9}$ and BWR $^{13}$ ) are contained in the WRIN module. The blowdown phase of the LOCA is calculated by the TWRAM module (most of the RELAP4/MOD5 code is contained in this module) with transient results stored on magnetic tape for plotting via the WROP module and to provide hydraulic conditions for the hot pin analysis by the FRAP module.

During the refill phase, the thermal-hydraulic equations used in the blowdown calculation are not solved. Instead, a series of special models (M. R. Buckner, SRL, personal communication to L. M. Shotkin, NRC, March 6, 1979) are invoked to represent the discrete processes of interest (for example: heat transferred to the Emergency Core Cooling System (ECCS) water in the lower plenum, hot wall delay time in the downcomer, etc.). The time required to fill up the lower plenum and the state of the fluid in the lower 


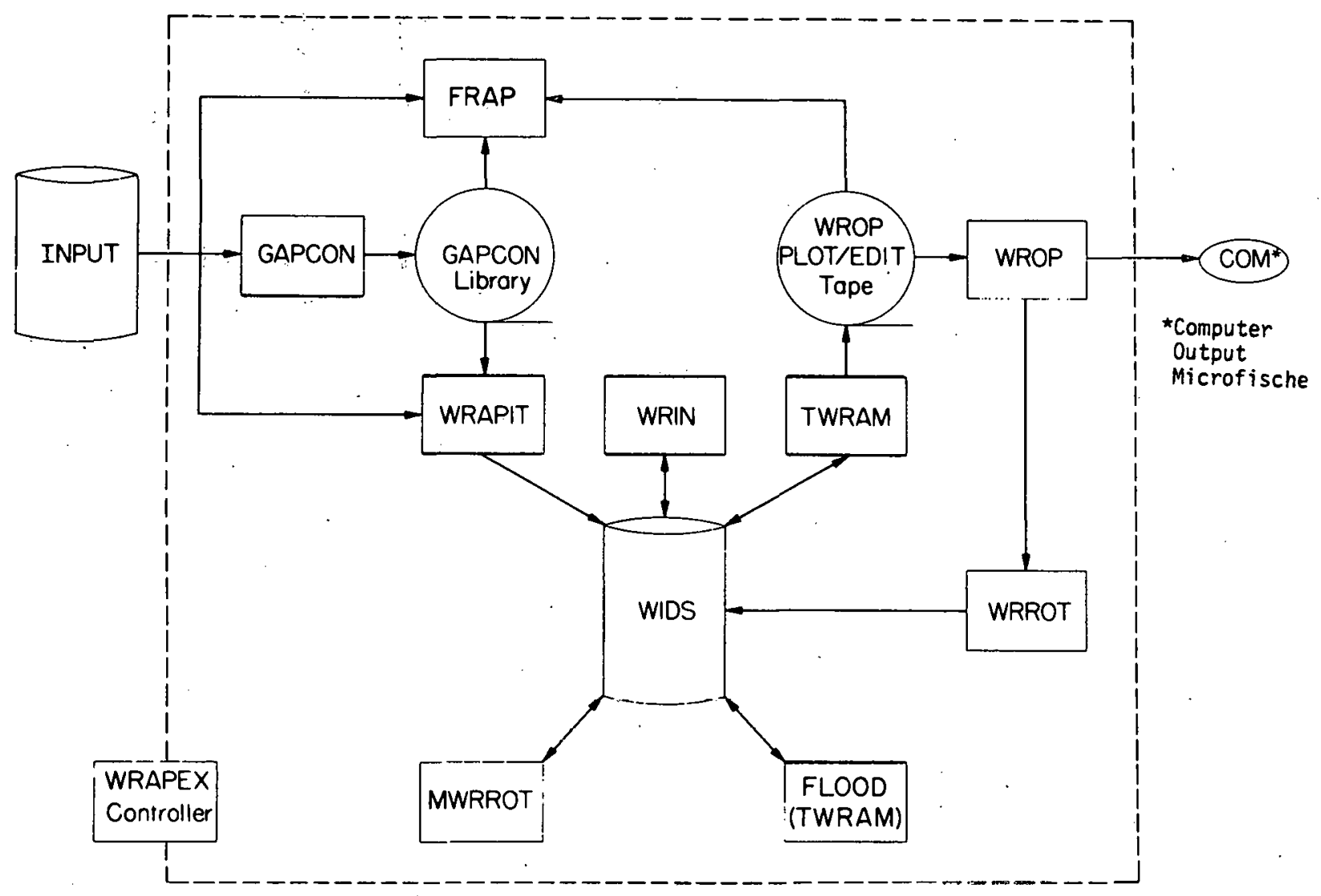

Figure 1. Overall Structure of WRAP-PWR-EM System 
plenum are the ultimate quantities of interest for the refill phase. After the refill time is computed, the normal heat conduction equations in WRAP are advanced from the end of bypass (EOB) to the end of refill. Adiabatic boundary conditions are used for the core heat slabs.

At the end of refill, the system is renodalized by the WRAPFLOOD interface routine and the reflood phase of the accident is calculated by the FLOOD option in WRAP. The time at EOB, the time at beginning of recovery, and selected coolant conditions in the core are transferred to FRAP for use in the hot pin analysis. The temporal sequence in which the various WRAP modules are executed is shown in Figure 2. Other capabilities within the system include the transient restart capability provided by WRROT and by MWRROT with the added capabilities of system renodalization and problem respecification. The overall execution of the various modules is controlled by the executive module, WRAPEX.

\subsection{NEW WRAP-EM COMPUTATIONAL CAPABILITIES}

The development of the WRAP-EM system for PWR analysis has required EM modifications to WRAP, the implementation of two new codes (GAPCON and FRAP) in the system, the development of a PWR steady-state procedure, and the development of a refill model. GAPCON and FRAP were implemented by converting the codes to JOSHUA modules, converting the card input to templated input JoSHUA records, 10 and defining and programing data interfaces to automate data transfer between the new and existing modules. A brief description of each of these new computational capabilities is provided below. A complete description of the input required for each of these new capabilities is provided in a companion document. 10

\subsection{EM Modifications to WRAP Blowdown Capability}

The initial WRAP system was based on RELAP4/MOD5/Version 65 developed at INEL. The EM development program required updating WRAP to RELAP4/MOD5/ Version 84 and implementing several modifications to provide an EM treatment of the PWR blowdown, refill, and reflood calculations. The modifications included:

- Vertical slip modeling modifications 14 neçessary to properly model gravity-induced velocity differences between liquid and gas phases.

- Implementation of new PWR reflood heat transfer EM models in the FLOOD subroutine in WRAP. 15

- Corrections to the fuel rod plenum temperature calculations. 14 

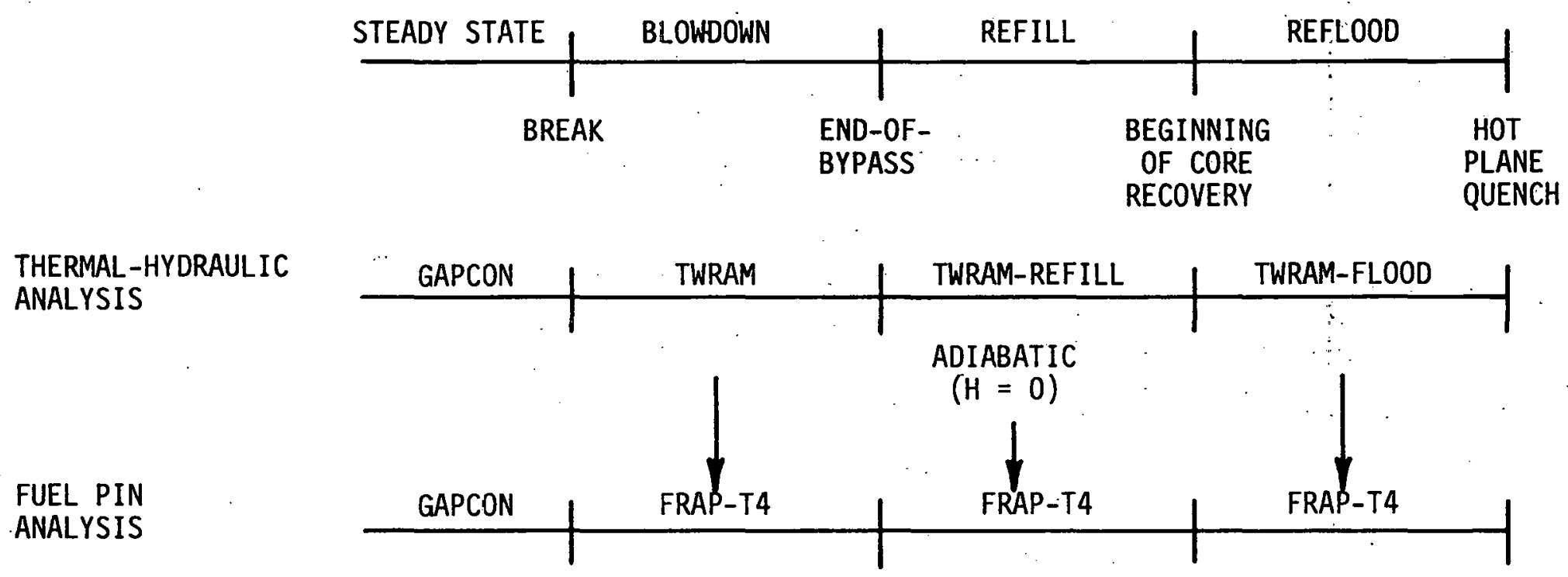

Figure 2. PWR Analysis Scheme 
Several other corrections 16 were made which included the proper calculation of potential energy contributions to the junction enthalpy when flow reverses as well as other minor coding modifications.

\subsection{Initial Fuel Condition Calculation}

The GAPCON module calculates pre-accident thermal conditions of the fuel rods: For a given fuel rod, GAPCON determines the gap conductance, temperatures, pressures, and stored energy as a function of the power history of the rod. These data are then used as initial conditions for the transient fuel models.

The GAPCON module implemented at SRL is essentially the GAPCON-THERMAL-2 code developed at Battelle Pacific Northwest Laboratories (BPNL), 11 including BPNL revision updates current to February 1979 (F. E. Panisko, BPNL, personal communication to $W$. G. Winn, SRL, February 24, 1978). The code has been modified to permit rod power histories to be calculated from reactor power history and rod peaking factors. Also the fuel and clad emissivities are no longer fixed by the code but are defined by inputs. Because the GAPCON module is to be used primarily for EM calculations, the input options given in Table 1 are selected. These options may be changed for stand-alone GAPCON calculational studies.

GAPCON calculations can be performed as part of the WRAP-EM modular path or stand-alone from the other calculations. In either procedure, GAPCON results may be stored in a data library. The stored GAPCON data are then used as input to WRAP and FRAP calculations. The GAPCON data transferred to WRAP require only two fuel rod descriptions: an average rod for the hottest fuel bundle, and an average rod for the other fuel bundles.

\subsection{Fuel Hot Pin Analysis}

FRAP computes temperatures, pressures; and dimensional changes for the hot pin in the core. The module is a JOSHUA version of the FRAP-T4-LACE 12,18 code developed at Idaho National Engineering Laboratory (INEL). To insure consistency between modules in the WRAP calculation, interfaces have been written which automatically transfer data to FRAP from GAPCON (initial fuel pin conditions), TWRAM (blowdown hydraulic conditions), and TWRAM-FLOOD (reflood hydraulic conditions). During refill (i.e. between end-of-bypass and beginning of core recovery) FRAP assumes adiabatic heatup of the core. 
Table 1 GAPCÔN Input Options for WRAP-EM Studies*

GAPCON Input Options

IPEAK = 1

IGAS** = 0

IRELOC $=1$

$s=0.0$

$\mathrm{CO}=0.0$

CRUDTH $=0.0$

$\mathrm{DBO}=0.0$

$\mathrm{NB}=0.0$

$\mathrm{HBC}=0.0$
Comment

Provides average rod power from input reactor power and peaking

Realistic EM option for gas release model

Realistic EM option for fuel relocation model

Sorbed gas model not provided in FRAP or WRAP.

CO gas not considered in FRAP or WRAP

Clad crud model not in FRAP

Secondary clad model not in FRAP

* These options are not required for stand-alone GAPCON calculational studies.

** These EM options are not the most conservative available (Reference 17): 
In determining the fuel rod response to a transient, FRAP models the mechanical deformation of the pin, the material properties (only oxide fuel and zirconium cladding allowed), and fill gas behavior. The transient hydraulic conditions in the core are used as boundary conditions in the form of surface heat transfer coefficients at selected axial levels. Both best-estimate and evaluation model calculations are possible.

\subsection{Refill Analysis}

The blowdown phase of the calculation ends when the net flow through the downcomer is into the lower plenum. This signals the onset of the refill phase and is labeled the EOB. At EOB the ECCS water which has been injected up to this point is subtracted from the inventory of water in the system through use of the Red Water/Blue water model ${ }^{16}$. At this point, the calculation exits the normal advancement of the thermal-hydraulic equations in TWRAM and invokes a series of phenomenological models which describe the processes of interest. The overall sequence is:

- Compute input flows (accumulator + ECCS).

- Compute refill time.

- Compute enthalpy of the fluid in the lower plenum.

- Compute core metal temperatures.

- Set up additional input for the reflood calculation.

Flow into the system is the sum of the accumulator flow and the ECcS flows. The FLOW4 model computes the accumulator flow rate from:

$$
W_{\text {new }}=W_{o 1 d}+144.0(32.174)(D T)(D P / I)
$$

whice $W_{0}$ ld is the flow rate at the old time, I is the inertia the junction exiting the accumulator, DP is the pressure drop across the junction, and DT is the timestep size. The components of the pressure drop are gravitational head, back pressure, and friction losses. Friction loss is evaluated from the flow at the previous timestep which makes the algorithm strongly explicit. However, this phase of the refill calculation requires relatively liclle computer time and the requirement of a very small timestep to solve the above equation is not onerous. The back pressure is derived by extrapolating a linear least squares fit of pressure data accumulated during blowdown. ECCS flows are taken from code input data. 
The refill time is calculated to be the sum of:

* the time to fill the cold legs one-half full,

free fall time,

hot wall delay time and,

- time to fill the lower plenum.

The time to fill the cold legs one-half full is computed by integrating the total flow rate. The hot wall delay time (THW) is calculated from the Creare correlation. ${ }^{19}$ The free fall delay time 16 (TFF) is:

$$
T F F=\sqrt{\frac{2 H}{32.174}}
$$

where $\mathrm{H}$ is the height of the downcomer. The time is advanced an interval equal to THW + TFF. At the end of this interval, ECC liquid is defined to be entering the lower plenum. Any liquid which filled the downcomer in excess of the one-third level during this interval is discounted (i.e. removed from the system). Finally, the flow equation is advanced further until the lower plenum is full. This final time is defined to be the beginning of core recovery (BOCREC).

The enthalpy of the fluid in the lower plenum is computed to be the mixed bulk enthalpy of the ECCS fluid at BOCREC (M. R. Buckner, SRL, personal communication to L. A. Shotkin, NRC, March 6 , 1979) The enthalpy is the sum of the enthalpy of fluid in the system at end of blowdown, the enthalpy of the injected fluid, the energy transferred to the fluid, and the energy deposited in the fluid from steam condensation. Wall heat transfer is calculated for three regions. In the cold legs, heat is transferred from one-half the total surface area to fluid at the temperature of injection. In the downcomer, heat is transferred from one-third the total surface area, which is assumed to be in contact with fluid $50^{\circ} \mathrm{F}$ warmer than the injection temperature. In the lower plenum, the fluid temperature is assumed to be that corresponding to saturation while the surface area is that of a segment of a sphere or of a vertical cylinder closed on the bottom by a hemisphere, filling up at the injection rate. ${ }^{20} \mathrm{~A}$ uniform heat transfer coefficient of $500 \mathrm{Btu} / \mathrm{hr}-\mathrm{ft}^{2}{ }^{\circ} \mathrm{F}$ is assumed unless the user supplies a different value. The energy transferred across the walls is added to that present in the fluid at EOB plus the energy content of the injection water. A user-specified fraction of the 
steam flow in the intact-loop cold legs and the vessel is calculated to condense completely and is added to the mass and energy inventory. The default value for this steam flow fraction is 1.0 . The resulting total enthalpy in the fluid is divided by the total mass of fluid to yield the average specific enthalpy. of the fluid.* The degree of subcooling of the lower plenum is calculated assuming the pressure is equal to the containment pressure.

Upon completion of this phase of the refill calculation, the code returns to the normal heat conduction equations solved in the blowdown calculation. The adiabatic boundary condition flag is set on for the core heat slabs and the code advances the heat conduction equations from EOB to BOCREC, using a fixed timestep of 0.01 seconds. This is the so-called adiabatic heatup calculation. Calculations for other heat slabs use EOB boundary conditions.

The power generation during refill is obtained by extrapolating the normalized power versus time computed during blowdown. The refill algorithm fits this data to the expression:

$$
P=A\left(T-T_{0}\right)^{B}
$$

where $P$ is the normalized power, $T$ the current time, $T_{0}$ the time of scraming, and $A$ and $B$ are the coefficients calculated from a least squares fit of data during blowdown.

The refill algorithms also prepare data for the subsequent reflood calculation. The accumulator flow equation is advanced further in time to get a complete table of flow versus time out to the point where the accumulator is empty. This data is then put in the form of a fill table for use in the reflood calculation after the curve has been shifted to account for the transport time from the point of injection to the lower plenum. 16 Equation 3 is used to generate a power curve for the reflood calculation. Finally, the time required for injecting the nitrogen remaining in the accumulator tank after the accumulator flow has ceased is calculated assuming the perfect gas 1 aw and choked isentropic flow (F. Beranek, SRL, personal communication to R. F. Audette, NRC, February 22, 1979). This parameter is used in the delta-P penalty model ${ }^{16}$ which accounts for aggravated steam binding effects due to nitrogen injected into the system.

* Any fluid discounted during the time interval $\mathrm{T}_{\mathrm{EOB}}$ to $\mathrm{T}(\mathrm{EOB}+\mathrm{THW}+\mathrm{TFF})$ is not included in this calculation. 


\subsection{Reflood Analysis}

The reflood analysis uses the FLOOD model developed at INEL and described in Reference 7. As implemented in WRAP-EM, the model has several new features added for user convenience. Some of the automated data transfer was described in the previous section. In addition, a pressure initialization procedure has been added. Given a single known pressure (normally containment pressure), the pressure distribution around the entire system is computed based on head differences and pressure drops due to any initial non-zero flows. Otherwise, the FLOOD model current in RELAP4/MOD5/Version 84 has been incorporated into WRAP-EM with no alterations,

\subsection{PWR Steady-State Procedure}

The RELAP4/MOD5 code provides no explicit procedure for initializing the transient thermal-hydraulic calculation. Instead, the user is required to generate the initial system state by a series of hand calculations to produce estimates of the state variables and then short transient runs to evaluate the reasonableness of the estimates. 'An automatic PWR steady-state procedure has been developed to eliminate this time-consuming process.

Instead, of specifying the volume variables and junction flows required by. RELAP, the WRAP user specifies the following quantities:

- Core inlet specific enthalpy.

- Pressure and liquid level in the pressurizer.

- Loop flow rates.

- Mixture level, mixture quality, inlet specific enthalpy, and pressure. on the secondary' side of the steam generator.

The procedure then computes the:

- Thermodynamic state of all control volumes.

- Flow splits within the core.

- Pump speeds.

- Heat exchanger characteristics.

A detailed description of the procedure is provided in Reference 9. 


\subsection{MODULAR INTERFACES FOR DATA TRANSFER}

The integration of the GAPCON, WRAP (WRAPIT, WRIN, and TWRAM), FRAP, and FLOOD modules to form the WRAP-EM system required the defining and programming of the following interfaces (see Figure 3):

- GAPCON/WRAP

- GAPCON/FRAP

- WRAP/FLOOD

- WRAP/REFILL

- FLOOD/FRAP

These interfaces automate the computational steps required to perform a complete LOCA analysis from break through reflood.

In general, hot assembly and average assembly fuel pin conditions as calculated by GAPCON are transferred to WRAP via the GAPCON/WRAP interface. The fuel pin conditions for the hot pin are also transferred to FRAP via the GAPCON/FRAP interface. The WRAP/FLOOD interface is a transfer of the data from WRAP at end of blowdown to FLOOD for initialization of the reflood calculation. Transient hot pin data during blowdown and reflood are. passed to FRAP via the WRAP/FRAP and FLOOD/FRAP interfaces, respectively. These interfaces will be described in the remainder of this section. A more detailed description of the data transferred by each interface is presented in Reference 10 .

\subsection{GAPCON/WRAP}

In the WRAP-EM computational system, GAPCON is used to determine fuel cod cunditions at the beginning of the LOCA analysis. These initial conditions are functions of power level, burnup, [ill gas pressure, etc. 'lhe data from the GAPCON calculation are transferred via the GAPCON/WRAP interface (see Figure 3) to WRAP (WRAPIT, WRIN, and TWRAM) which calculates the blowdown phase of the LOCA.

The data transfer between GAPCON and WRAP is not straightforward because the fuel models in the two codes differ. For example, GAPCON models a single fuel pin allowing up to 20 axial nodes for detail. WRAP, on the other hand, models the complete core as one or two (or possibly three) stacks of heat slabs. One stack may represent the hot bundle while the other models the remainder of the core. Thus, the data transferred from GAPCON to WRAP must be collected, stored, and interpolated by the interface before being used in WRAP. 
Fuel Initial Conditions

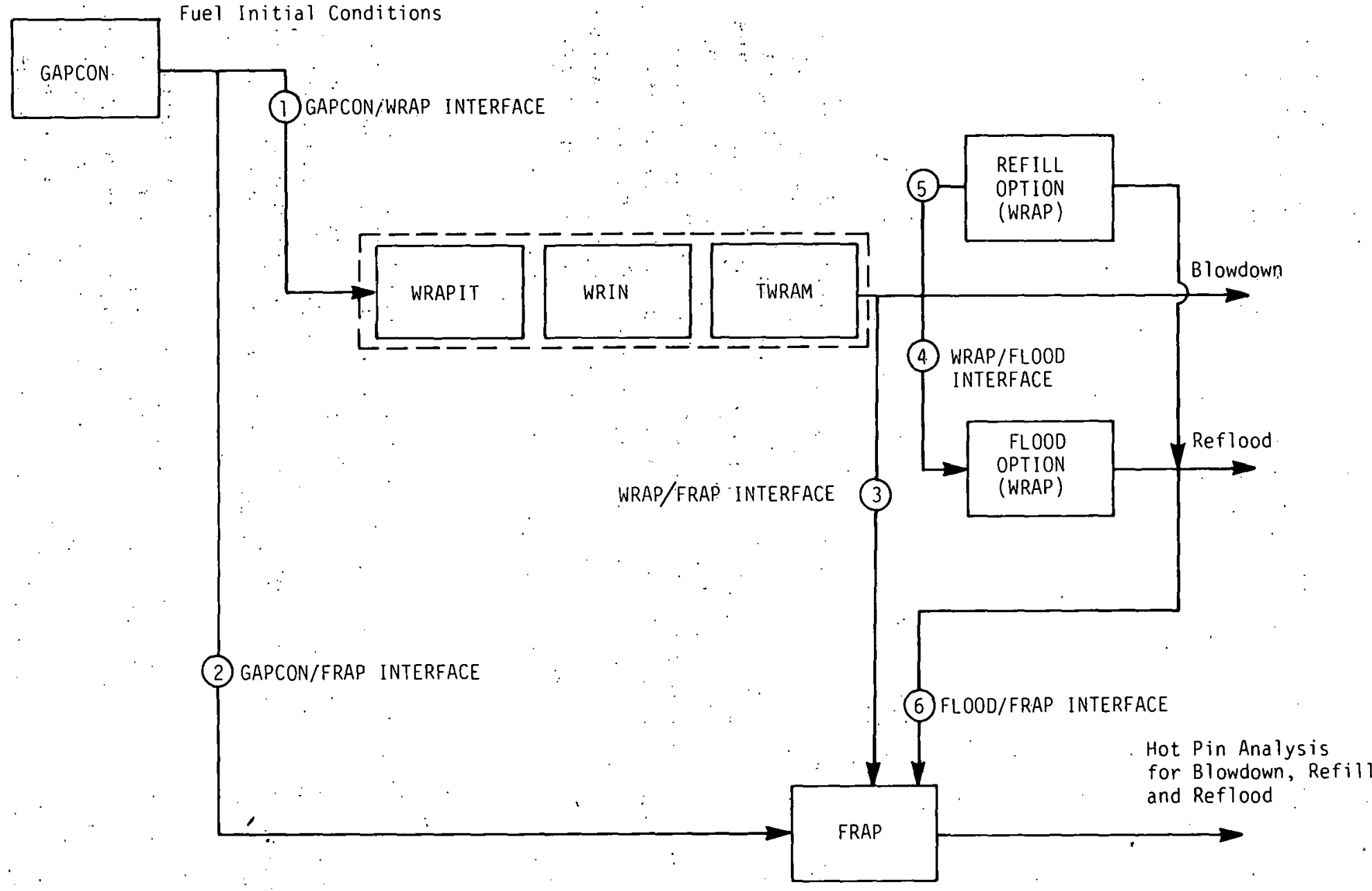

MODULAR INTERFACES

Figure 3. Modular Interfaces 
Dat a transferred between GAPCON and WRAP is specified for a given pin(s). For example, hot channel and average channel heat slab conditions may be determined by 'typical' hot rod and

'typical' average fuel rod calculations done with GAPCON. In the interface, the GAPCON 'typical' pin data may be scaled by the number of fuel rods per stack to obtain WRAP heat slab data. The data transferred by the interface includes the fuel rod geometry (before and after burnup), power, fuel density, and gap heat transfer factors including fission gas composition and gram-moles of fission gas. Where GAPCON data does not coincide with the axial mesh locations used in WRAP, the WRAP heat slab data is linearly interpolated from the GAPCON data.

\subsection{GAPCON/FRAP}

Cold state fuel pin dimensions are passed from the GAPCON data base to FRAP which modifies the data to model the appropriate hot state. This eliminates the need to duplicate input data for the two codes and insures consistency of data in GAPCON and FRAP. Options used in the two codes are checked for consistency and flagged if not identical.

GAPCON results which are transferred to FRAP include power specifications at the time of the accident (e.g. average linear power and axial power distribution) and burnup dependent data (e.g. average burnup, amount of gas in the gap, and the composition of the gas). Also any fission-induced swelling in the fuel and clad creep strain is transferred for each axial level.

\subsection{WRAP / FRAP.}

Core hydraulic conditions during the blowdown are transferred to FRAP to be used as boundary conditions for the hot fuel pin thermal analysis. Two options are available to select the parameters to be passed. The first option passes the time-dependent coolant preecure, temperature, and enthalpy for the upper and lower plena and each hot channel volume used in the blowdown calculation. From these parameters, FRAP calculates the axially dependent surface heat transfer coefficients. The second option transfers only the coolant pressure and temperature for each hot channel volume and the surface heat transfer coefficient for each heat slab modelling the hot pin in the blowdown calculation.

Regardless of the option chosen, the power history of the hot pin turing blowdown is also transferred. All data are transferred from the plot tape generated during blowdown. The number of data points passed is selected by the user. 


\subsection{WRAP/REFILL-FLOOD}

The refill model picks up its data from the EOB data base. There is no external interface as such since the refill calculation and the blowdown calculation are both performed in the same module. The required data transfer is carried out based on the user's identification of the specific volumes of interest: the cold legs, the downcomer, and the lower plenum. As needed, flow areas, loss coefficients, hydraulic diameters, volumes, enthalpies, elevations, saturation temperatures, densities, specific heats, slab temperatures, thermal conductivities, volumetric heat capacities, and liquid inventories are extracted from the data base.

The reflood interface consists of a few automated features in the input processing module WRAPIT which can be invoked for the FLOOD calculation. The containment pressure may be extracted from the data base with the remaining system pressures then calculated by marching around the system. Volume temperatures are initialized to the corresponding saturation temperatures. As needed, the user may specify that the data base extract the lower plenum subcooling temperature, the clad surface temperatures, the fraction of channel blockage, and the core outlet enthalpy. In general, a renodalization is carried out in going from the blowdown/refill calculation to the reflood calculation. In part, this renodalization is supported by the renode module RENPRE. This is a semi-automatic interface due to the complex nature of the renodalization.

\subsection{FLOOD/FRAP}

This module is based on the FLOOD/FRAP interface developed at. INEL: 21 . The time-dependent parameters passed are (1) core inlet coolant temperature, (2) reflood rate, (3) core pressure, and (4) collapsed liquid level. Since these values can oscillate rapidly during the flooding process, a data smoothing routine was added by INEL to the data transfer module. 21 FRAP uses this data in the FLECHT correlation to predict heat transfer coefficients during the reflood stage.

\subsection{ZION TEST PROBLEM}

To verify the operability of the WRAP-PWR-EM system, a LOCA analysis was performed for the Zion Plant.* The analysis was performed in parallel with an identical calculation at INEL and is a part of the code verification effort. In general, the agreement between the two calculations was very good. The accident model represents a double-ended guillotine pipe break on the primary pump outlet side in one of the cold legs. The initial power was $3303 \mathrm{MN}(\mathrm{th})$.

* Calculations for semiscale and LOFl tests were also made as part of the code verification. 


\subsection{Blowdown Nodalization}

The nodalization used for the blowdown and refill calculations is shown in Figures 4 and 5 . The model consists of 57 volumes, 78 junctions, and 38 heat slabs. To maintain the parallelism with the INEL calculation, the naming convention for the components reflected the original numbering. Thus, volumes were identified as VNXX.Y where XX was the original volume number and $Y$ the assigned part name (for example the pressurizer was named VN30. INTLOOP). Junctions were named JNZZXXWW.Y where XX was the original junction number, $\mathrm{ZZ}$ the original volume number on the inlet side of the junction, and $W W$ the original volume number on the outlet side (for example, the junction exiting the pressurizer was named JN303029. INTLOOP). A similar convention was used for slab naming: HTZZXXWW.Y, where XX was the slab number, $Z Z$ the volume number on the left (00 if none), and WW the volume number on the right: The system was divided up into three parts: the intact loop (INTLOOP) whose boundaries were defined by Junctions $6 \hat{6}$ and 31 , the broken loop (BRKLOOP) whose boundaries were defined by Junctions 65 and 32 , and the reactor (REACTOR) for all the remaining in-vessel components.

\subsection{Reflood Nodalization}

The nodalization used for the reflood calculation is shown in Figure 6. Again, the same naming conventions were used as for the blowdown calculation. To maintain the parallelism with INEL's calculation, INEL's nodalizatiou was used. In general, a slightly different nodalization is desirable: the steam/water slip Junctions 22 and 29 should lead directly to containment rather than Volume 17 (this requirement was technically met by assigning a very large volume to Volume 17); the steam generator secondary side volumes should each have been split into two volumes, one a steam dome, the other a water volume.

\subsection{Computational steps}

Utilization of the WRAP-PWR-EM system for a LOCA analysis led through the following steps:

- Fuel data was already specified by the INEL problem setup, thus GAPCON was not executed under WRAP. A demonstration of this link was provided earlier in the work described in Reference 2 .

- All input was processed through the WRAPIT module. 


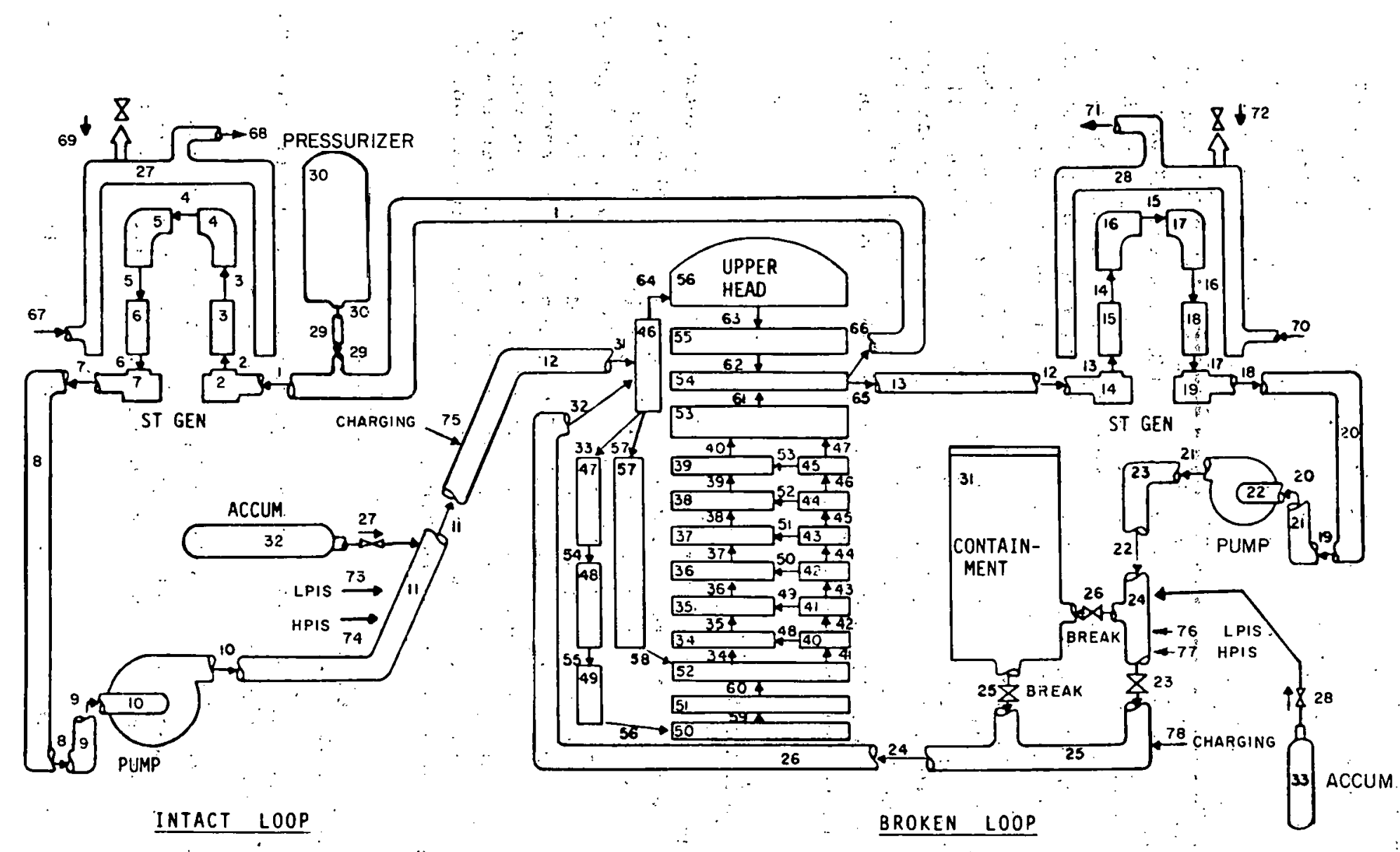

Figure 4. System Nodalization Diagram for Zion Blowdown Model 


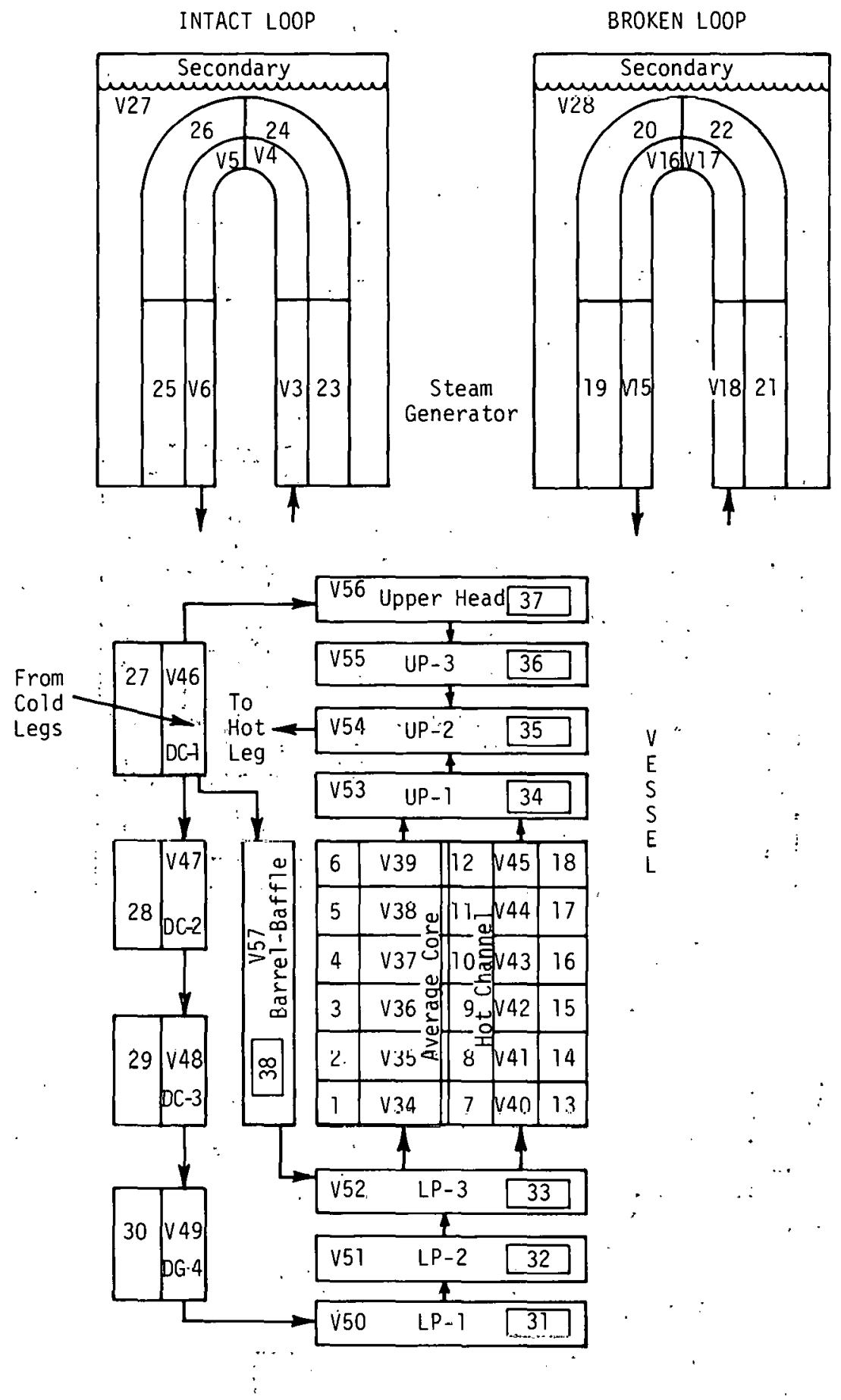

Figure 5. Heat Slab Nodalization Diagram for Zion Blowdown Model 


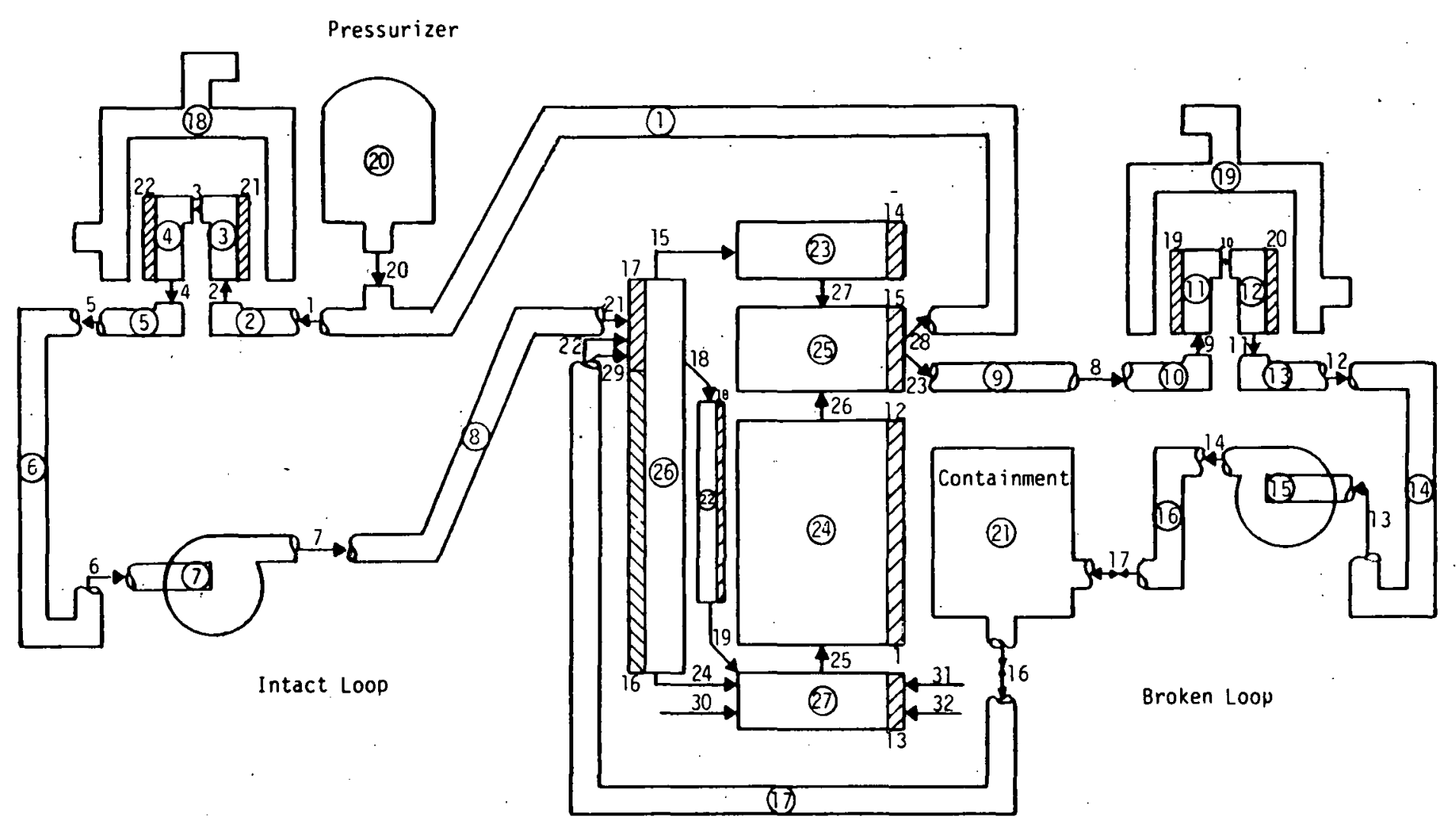

FIGURE 6. Nodalization Diagram for Zion Reflood Model 
- Accessing the WIDS data set generated by WRAPIT, WRIN was used to determine the thermal-hydraulic state of the reactor at the beginning of the LOCA. The results of the PWR steady-state calculation are summarized in Table.2: However, the actual calculation used the RELAP4/MOD7 self-initialization result in order to maintain parallelism with INEL's calculation. The latter initial state is also summarized in Table 2...

- Beginning with the initial state as determined with WRIN, TWRAM was used to analyze the system during the blowdown phase of the transient.

- At end of bypass, the refill models in TWRAM were automatically activated and the calculation proceeded to the beginning of core recovery.

- The reflood calculation was performed with the FLOOD option in TWRAM.

- The hot pin analysis was performed with. FRAP using data automatically passed from TWRAM and FLOOD.

- Finally, plots of the entire sequence of calculations were generated using the WROP module.

It is significant,to note that most of the calculational sequence is automated, i.e., no user intervention is required between the computational steps. The sole exception is the transition to the reflood calculation. Since this requires a renodalization of the geometry, the user is required to intervene and define the geometrical specifications for that transformation.

\subsection{Re.sults}

Selerter results for the complete WRAP-PWR-EM calculation for the postulated LOCA are presented here. EOB was predicted to occur at 30.4 seconds and beginning of core recovery at 43.7 seconds. The reflood calculation was terminated at 155 seconds with quenching of the hottest plane at 140 seconds. The peak clad temperature during the reflood calculation was $1610^{\circ} \mathrm{F}$ and occurred at 80 seconds. The hot pin analysis using FRAP predicted fuel pin rupture shortly after 30 seconds and an ultimate peak temperature in excess of $2500^{\circ} \mathrm{F}$. 
Table 2 Initial States

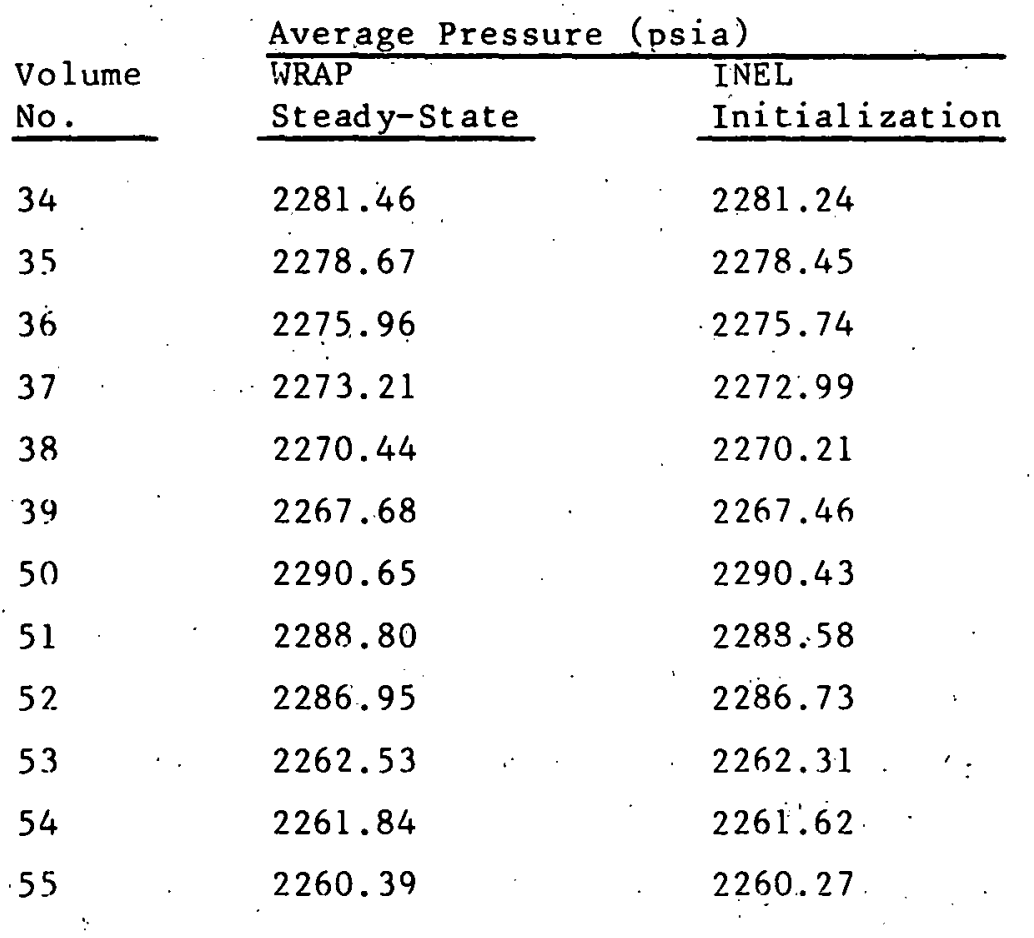

\begin{tabular}{lll}
$\begin{array}{l}\text { Junction } \\
\text { No. }\end{array}$ & \multicolumn{2}{l}{$\begin{array}{l}\text { Average Flow } \\
\text { WRAP } \\
\text { Steady-State }\end{array}$} \\
34 & 39819.5 & $\begin{array}{l}\text { INEL } \\
\text { Initialization }\end{array}$ \\
35 & 39820.0 & 39819.8 \\
36 & 39820.6 & 39819.8 \\
37 & 39821.5 & 39819.8 \\
38 & 39822.4 & 39819.8 \\
39 & 39823.0 & 39819.8 \\
40 & 39824.3 & 39819.8 \\
50 & 0.885 & 0.0 \\
52 & 0.595 & 0.0
\end{tabular}




\section{4 .1 TWRAM}

Core Inlet Flow

The hot channel core inlet flow is shown in Figure 7. This represents the flow in Junction 41 in Figure 1. At time zero, the flow is $2071 \mathrm{bm} / \mathrm{sec}$, upward through the core. Very shortly after the break occurs, the flow through the core reverses. From 2 to 13 seconds, the flow returns to an upward direction, with several negative spikes. Beyond 14 seconds, the flow is again predominately downward. The average core flow follows a very similar pattern.

\section{Core Quality}

The average quality in Volume 42 is shown in Figure 8 . Those times at which the core inlet flow in Figure 7 approaches zero are seen to coincide with high qualities in Figure 8 . The volume essentially dries out around 5 seconds and then again around 17 seconds.

\section{Slab Surface Temperature}

The temperature history for the hottest slab in the hot channel is shown in Figure 9. The temperature attains local maxima at those times when the quality in the adjacent volume approaches 1.0 (see Figure 8). Beyond 30 seconds, the slab goes into the adiabatic heatup period of the refill phase and attains a maximum of $1611^{\circ} \mathrm{F}$ at the end of refill.

\section{Upper Plenum Pressure}

The pressure history for volume 54 is shown in Figure 10. The initial pressure is 2262 psia. Immediately after the break, the pressure drops to 1480 psia. At EOB, the pressure is down to 70 psia.

\section{Break Flow}

The cold leg break flow (Junction 25) is shown in Figure 11. tairly large oscillations in the fluw during the interval 2.5 to 5.0 seconds coincide with the large oscillations in core inlet flow in Figure 7 and the initial core dry out in Figure 8 . 


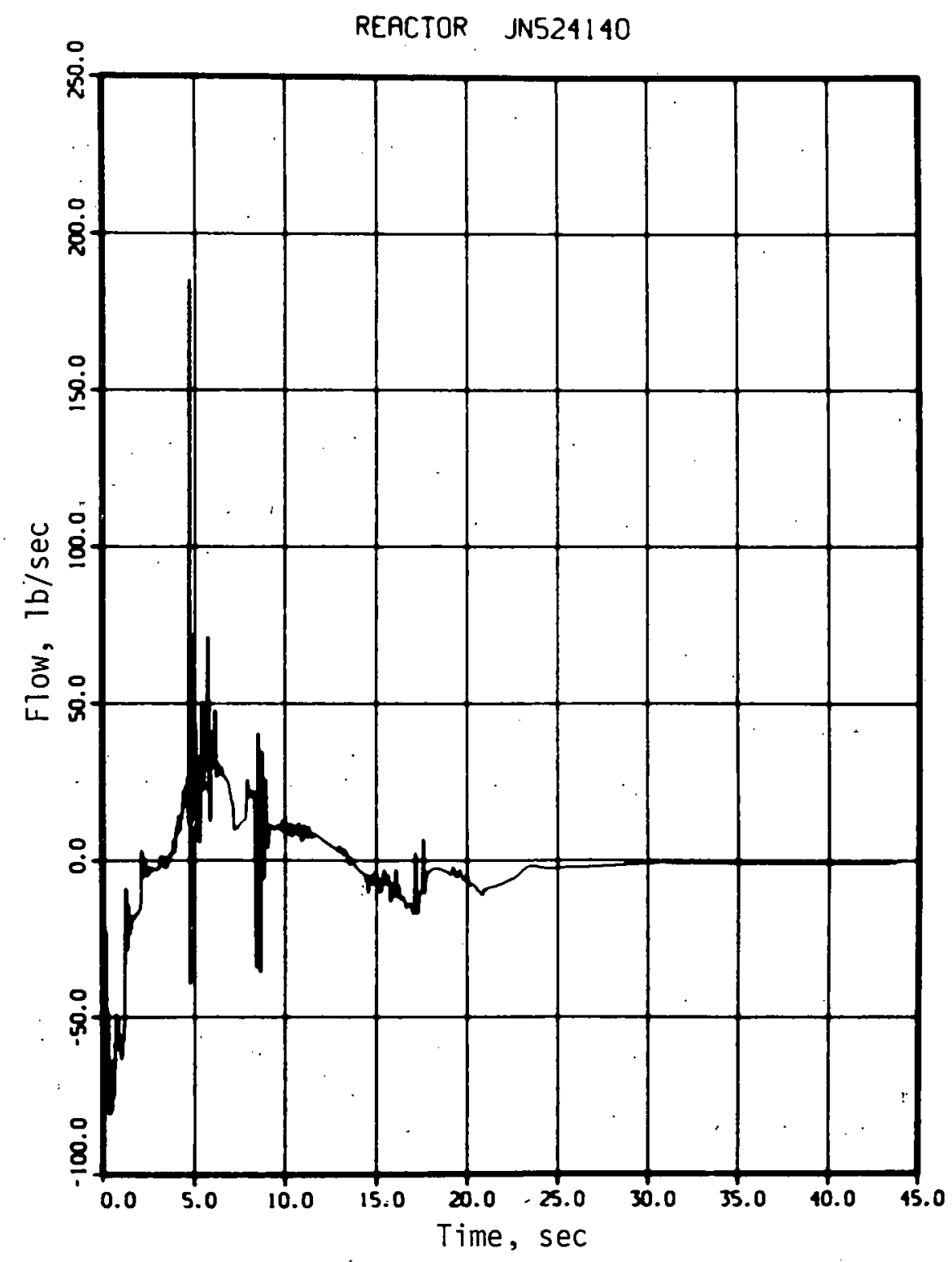

Figure 7. Hot Channel Core Inlet Flow (Junction 41) 


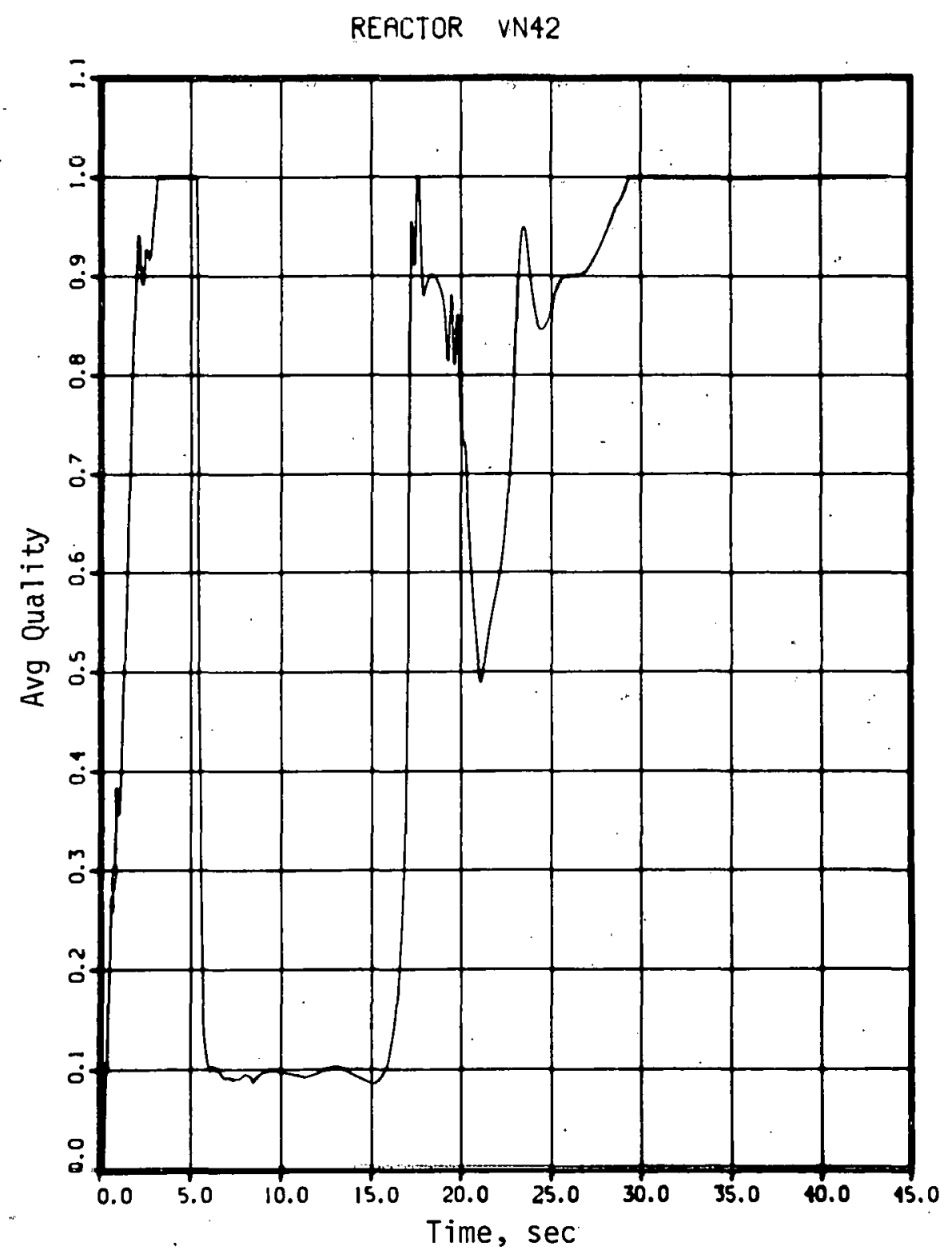

Figure 8. Core Average, quality (Volume 42) 


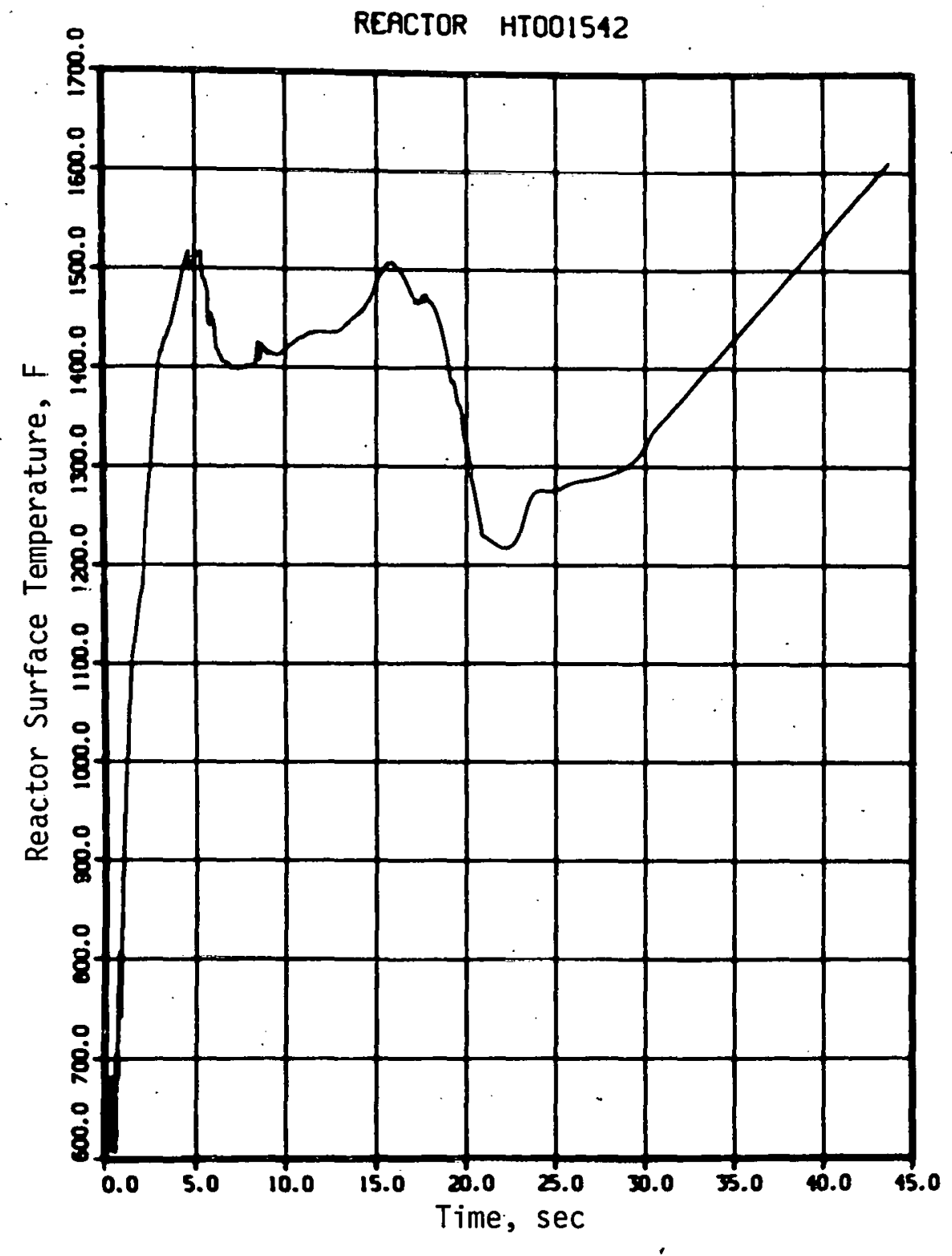

Figure 9. Slab Surface Temperature (Slab 15) 


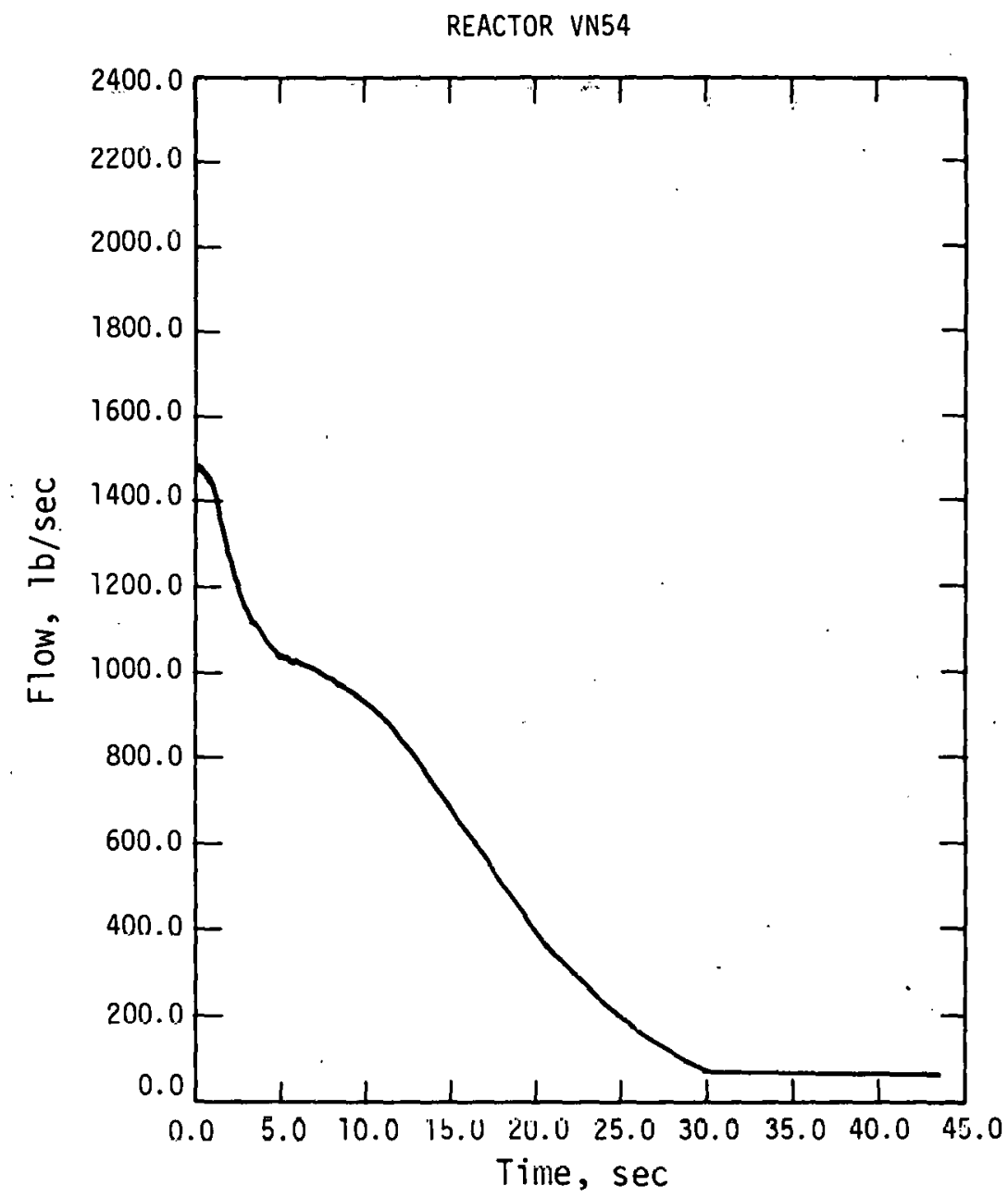

Figure 10. Upper Plenum Pressure (Volume 54) 


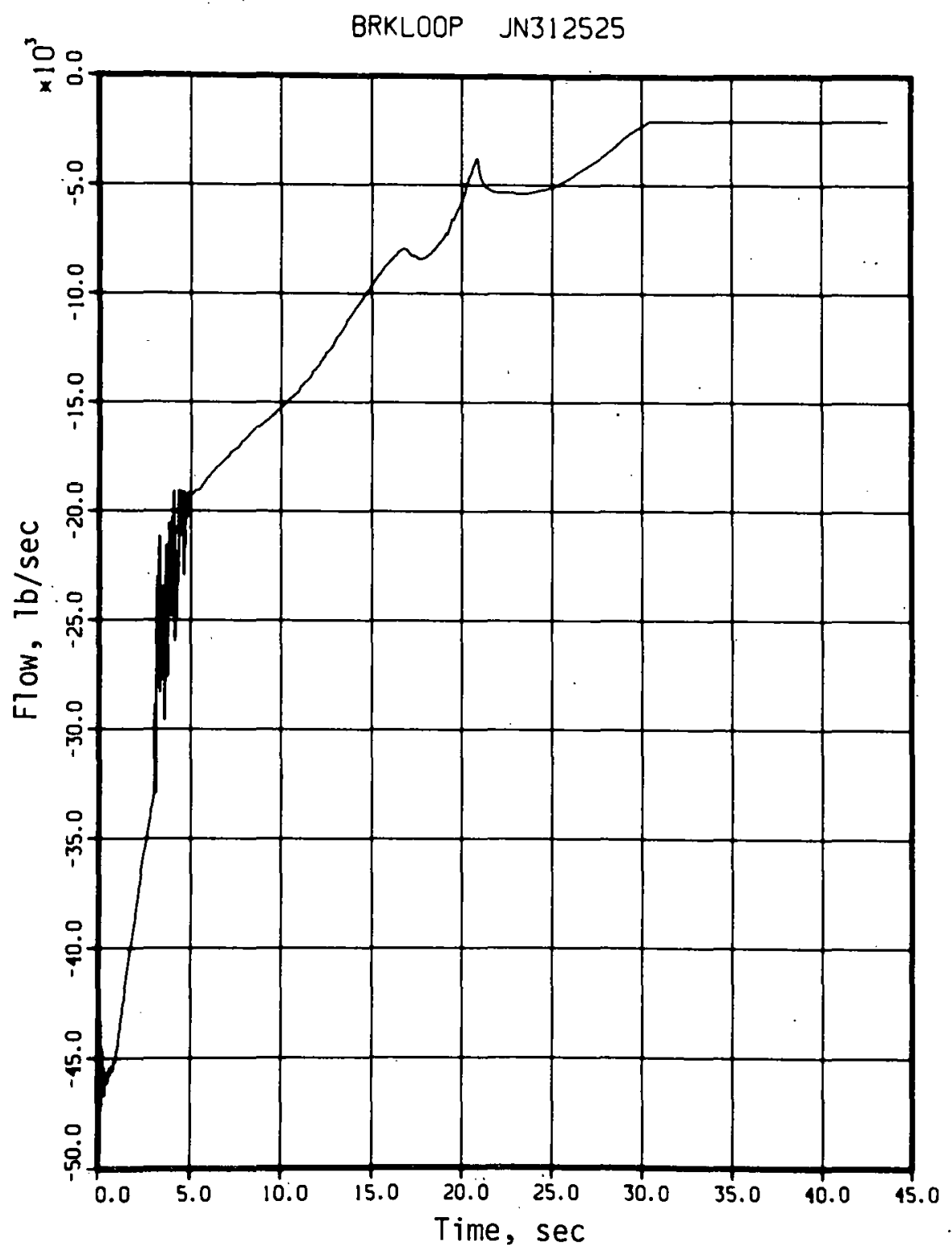

Figure 11. Cold Leg Break Flow (Junction 25) 


\section{4 .2 FLOOD}

Core Inlet Flow

The core inlet flow during reflood is shown in Figure 12. The time zero value was $2290.31 \mathrm{lbm} / \mathrm{sec}$. The flow undergoes several significant oscillations before settling down to a value around $400 \mathrm{lbm} / \mathrm{sec}$. These initial oscillations are probably callsed by some small imbalance in the initial state (i.e. start of FLOOD).

\section{Core Mixture Level}

The core mixture level is shown in Figure 13. The initial value was 3.0 feet. It should be emphasized that the heated part of the core begins at 3.323 feet, thus the core proper extends from 3.323 to 15.323 feet. For the first 60 seconds, the mixture level drops in and out of the core. After 60 seconds the level never drops below the bottom of the heated part of the core.

Hottest Slab Surface Temperature

The time history of the core slab* which reaches the highest surface temperature is shown in Figure 14. The initial surface temperature is $1361^{\circ} \mathrm{F}$. A temporary temperature excursion occurs in the first 20 seconds during the period of oscillatory core iulel flow. The peak surface temperature of $1610^{\circ} \mathrm{F}$ occurs at 80 seconds and quenching occurs at 140 seconds. The slab extends from 7.0 to 8.0 feet, measured from the bottom of the heated core. This hottest slab surface temperature should not be confused with the hot pin peak clad temperature calculated in FRAP (see below).

\section{4 .3 FRAP}

The basic FRAP input (pin dimensions, nodalization, axial power distribution, model selections, etc.) was provided by INEL. 22 For the analysis with an initial reactor power of 3303 MW, the initial average linear power density for the hot pin is $10.555 \mathrm{kw} / \mathrm{ft}$ (peak power at elevation of $6.0 \mathrm{ft}$ is $14.76 \mathrm{kw} / \mathrm{ft}$ ). Fluid conditions and a power history were passed from the blowdown and reflood calculations discussed above.

* For FLOOD, a single stack of heat slabs models the entire reactor. Temperatures of high powered fuel pins will be greater. 


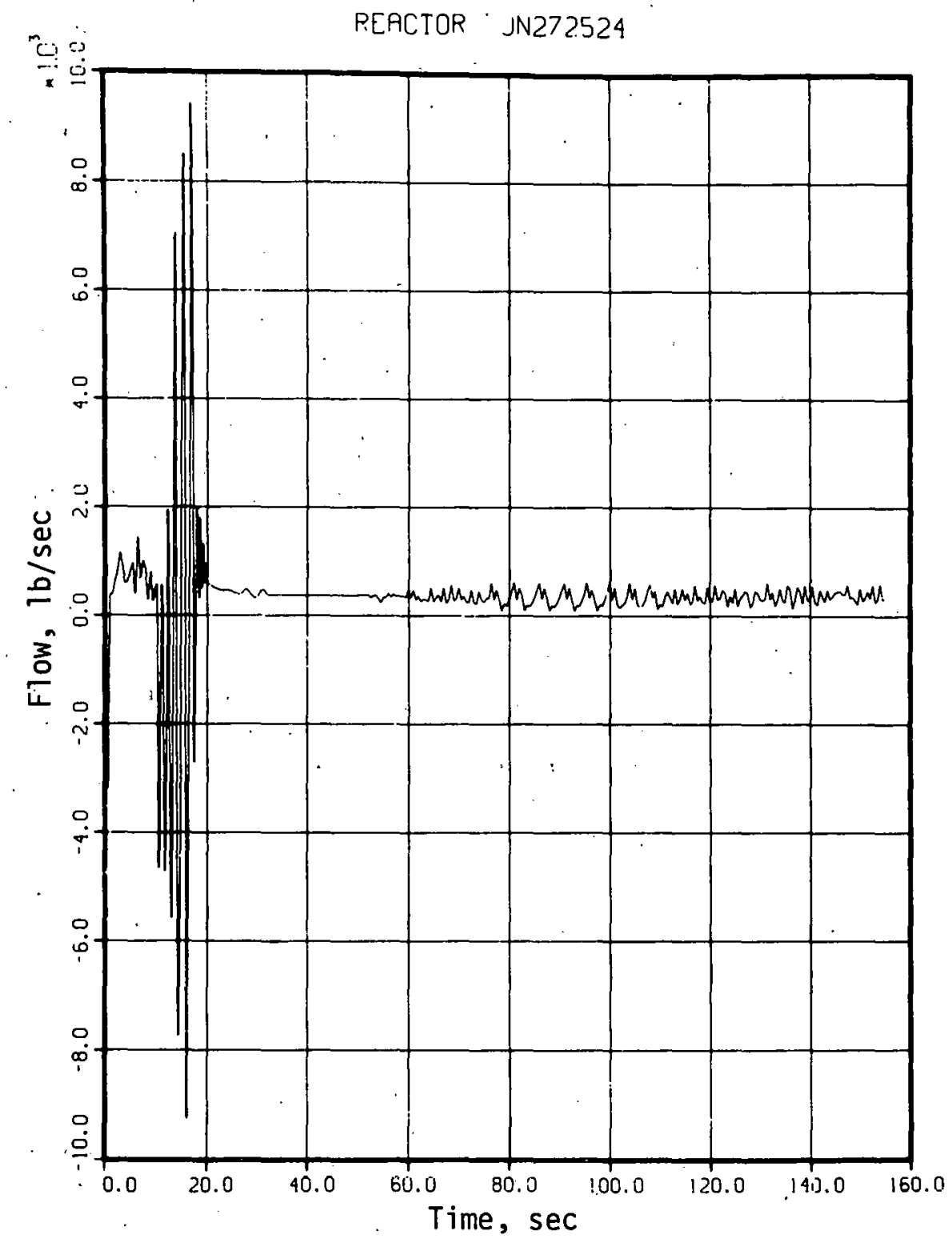

Figure 12. Core Inlet Flow During Reflood 


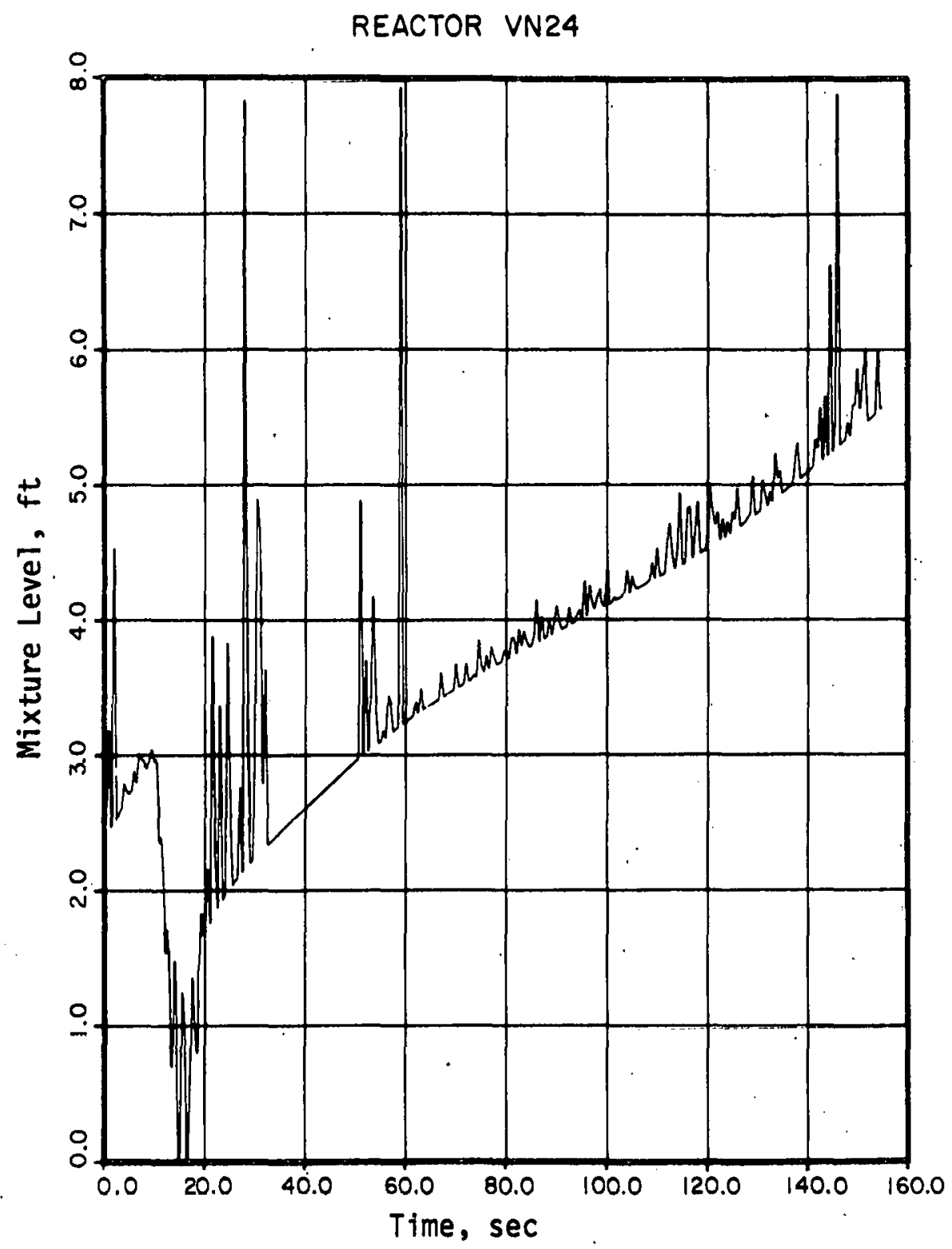

Figure 13. Cote Mixture Level During Reflood 


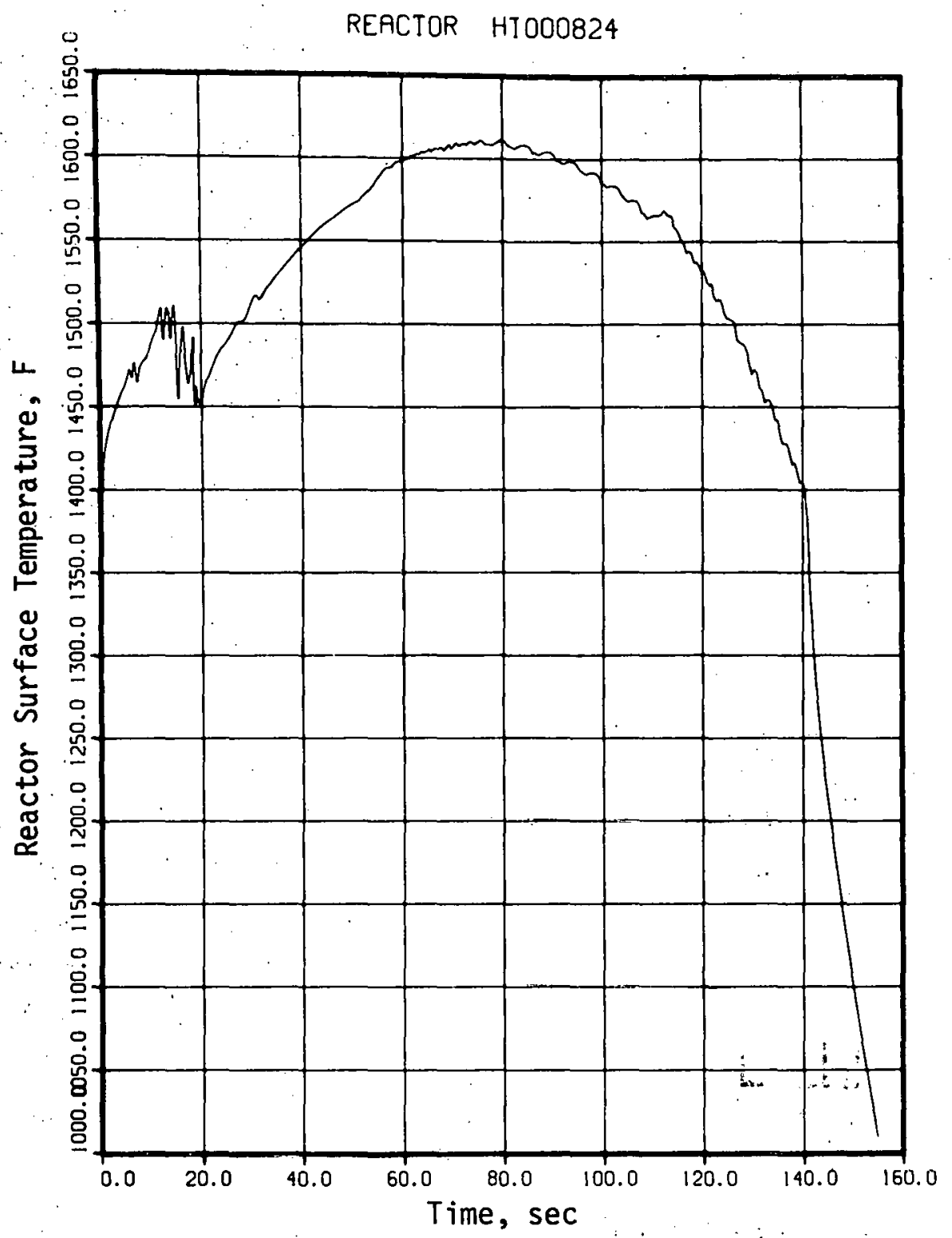

Figure 14. Hottest Slab Surface Temperature During Reflood 


\subsubsection{Clad Surface Temperature}

Figure 15 shows the behavior of the clad surface temperature at elevation of $8.4 \mathrm{ft}$. This elevation corresponds to the node attaining the peak clad temperature $\left(2300^{\circ} \mathrm{F}\right)$ during the transient calculation. The initial temperature response follows the coolant flow rate (Figure 7 ) with an immediate rise due to flow reversal and a temperature decrease as positive flow returns. The temperature again climbs since the flow is low and reaches a local maximum at $18 \mathrm{sec}$ as the core quality (Figure 8 ) reaches 1.0 . A reduction in core quality provides better heat transfer thus reducing the temperature again until the fluid in the core is nearly depleted. At 30 seconds, EOB signals the beginning of the refill period during which the core is assumed to heat adiabatically. The temperature continues to rise as the quench front rises through the lower regions of the core. The FRAP calculation was terminated at about 150 seconds, the hot plane quenching time in the FLOOD calculation. If the FLOOD and FRAP calculations had been continued, the temperature in Figure 14 would have continued rising until the quench front reached 8.4 feet elevation.

\subsubsection{Fuel Pin Rupture}

FRAP calculates that the hot pin ruptures at the 6 feet elevation (the node corresponding to the highest power) shortly after 35 seconds as evidenced by the clad hoop strain behavior (Figure 16).

\subsubsection{Computer Time and Storage}

The CPU time and storage requirements for the various steps in complete calculation are given in Table 3. The calculations were performed on an IBM $360 / 195$ computer.

\subsection{WRAP-EM AVAIILABLLL'TY AND INSTALLATION REQUIREMENTS}

The WRAP-EM System has been developed for operation under the JOSHUA Operating System. ${ }^{8}$ JOSHUA was developed at SRL in 1968 and 1969 and has been in production use since 1970 on IBM computers. Associated with the JUSHUA system is a CRT terminal system which provides facilities for problem setup and modification as well as job execution. For IBM computers having no terminal facilities, a JOSHUA Terminal Simulator ${ }^{6}$ has been developed to simulate JOSHUA operations via card input for execution in the batch mode. Currently, a CDC-compatible version of the JOSHUA system does not exist. 


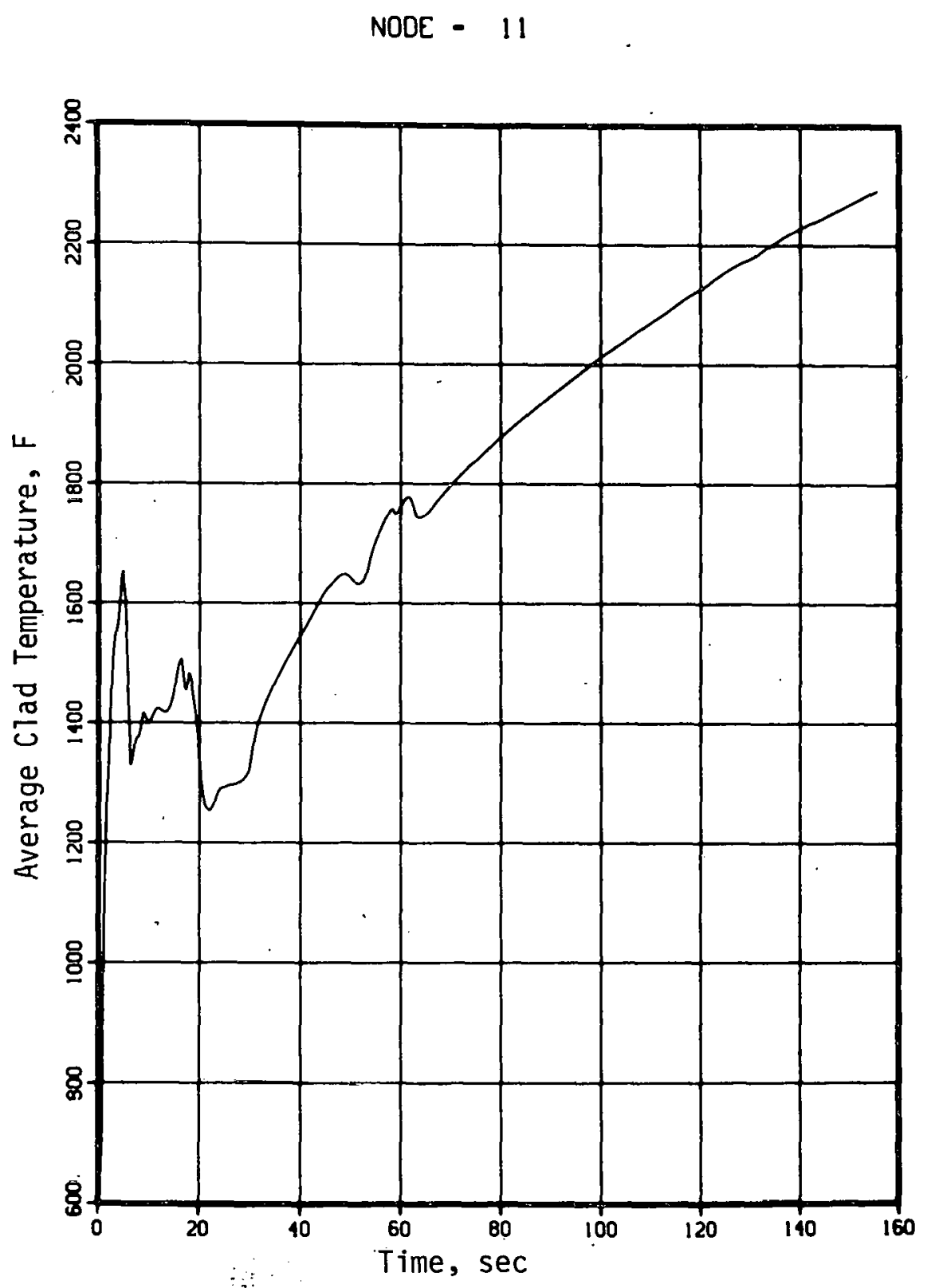

Figure 15. Clad Surface Temperature at $8.4 \mathrm{Ft}$ 


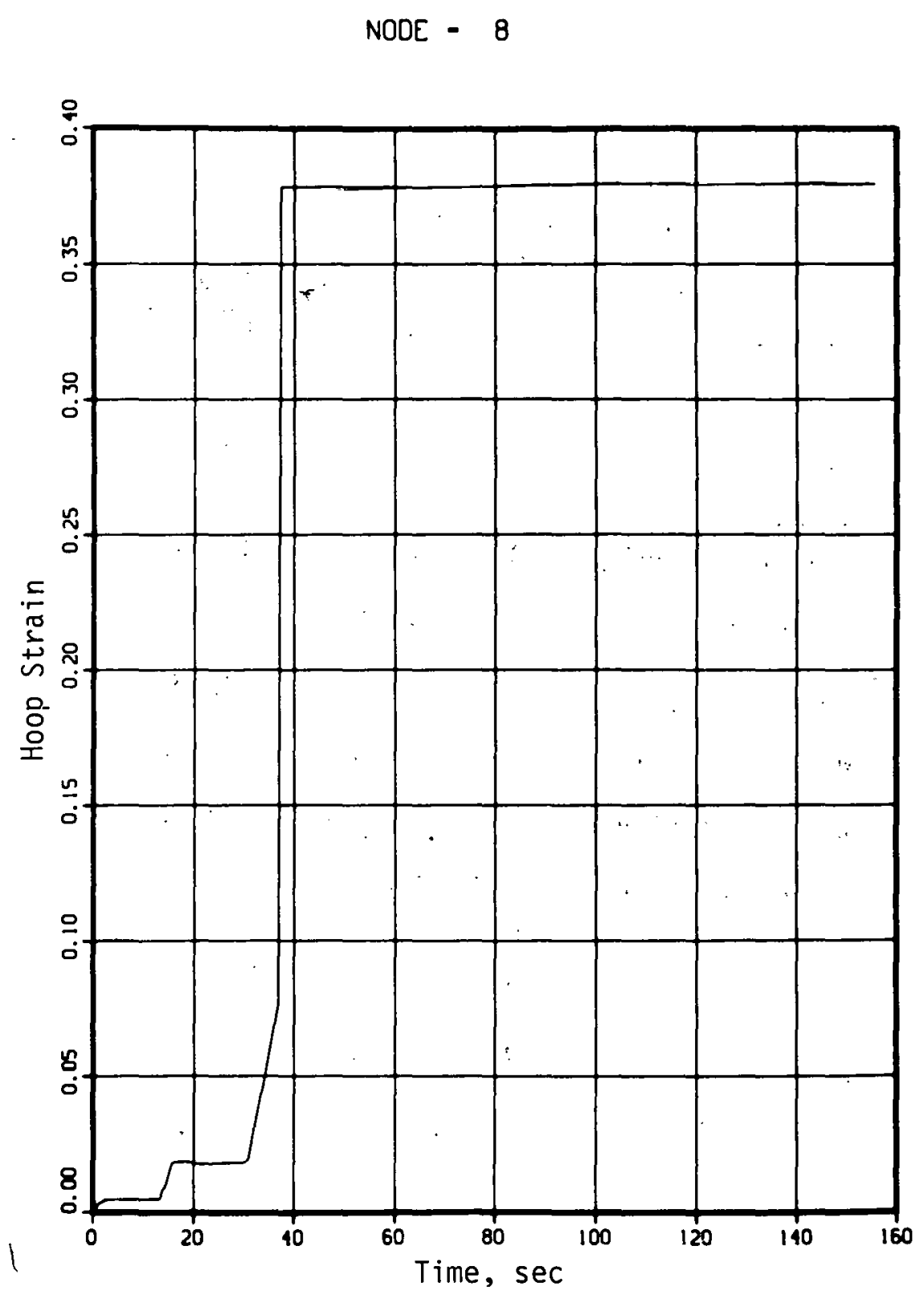

Figure 16. Hoop Strain at $6.0 \mathrm{Ft}$ 


\begin{tabular}{|c|c|c|}
\hline Step & $\begin{array}{l}\text { CPU Time } \\
(\mathrm{min})\end{array}$ & $\begin{array}{l}\text { Core Size } \\
\text { (bytes) }\end{array}$ \\
\hline WRAP IT & 0.3 & $694 \mathrm{~K}$ \\
\hline WRIN & 0.1 & $805 \mathrm{~K}$ \\
\hline $\begin{array}{l}\text { TWRAM } \\
\text { (blowdown and refil1) }\end{array}$ & 124.9 & $1071 \mathrm{~K}$ \\
\hline TWRAM (FLOOD option) & 145.4 & $950 \mathrm{~K}$ \\
\hline FRAP & 7.6 & $1100 \mathrm{~K}$ \\
\hline WROP (for TWRAM) & 8.6 & $1000 \mathrm{~K}$ \\
\hline NROP (for FRAP) & 2.0 & $1000 \mathrm{~K}$ \\
\hline Total CPU time & 288.9 & \\
\hline
\end{tabular}




\subsection{REFERENCES}

1. U.S. Nuclear Regulatory Commission, "Acceptance Criteria for Emergency Core Cooling Systems for Light Water-Cooled Nuclear Power Reactors," Federal Register, Vol. 39, No. 3, January 1974,10 CFR, Part 50 .

2. M. R. Buckner, et al, "The BWR Loss-of-Coolant Accident Analysis Capability of the WRAP-EM System," NRC Report NUREG/CR-0713 (DPST-NUREG-78-2), April 1979, Savannah River Laboratory, E. I. du Pont de Nemours \& Co., Aiken, SC.

3. N. H. Kuehn, et al, "WRAP-BWR Verification Studies," NRC Report NUREG-CR-1680 (DPST-NUREG-80-3), to be issued in 1980, Savannah River Laboratory, E. I. du Pont de Nemours $\&$ Co., Aiken, SC.

4. M. V. Gregory, et al, "WRAP-PWR Verification Studies," NRC Report NUREG/CR-1681 (DPST-NUREG-80-4), to be issued in 1980, Savannah River Laboratory, E. I. du Pont de Nemours \& Co., Aiken, SC.

5. M. M. Anderson, "WRAP - A Water Reactor Analysis Package," NRC Report DPST-NUREG-77-1, June 1977, Savannah River Laboratory, E. I. du Pont de Nemours \& Co., Aiken, SC.

6. M. V. Gregory, "User's Guide to Input for WRAP - A Water Reactor Analysis Package," NRC Report DPST-NUREG-77-2, June 1977, Savannah River Laboratory, E. I. du Pont de Nemours \& Co., Aiken, SC.

7. "RELAP4/MOD5 - A Computer Program for Transient ThermalHydraulic Analysis of Nuclear Reacturs and Related Systems User's Manua1," NRC Report ANCR-NUREG-1335, 1976, Idaho National Engineering Lahoratory, Aerojet Nuclear Company, Idaho Fills, ID.

8. H. C Honeck, "The JOSHUA System," USERDA Report DP-1380, 1975, Savannah River Laboratory, E. I: du Pont de Nemours \& Cn., Aiken, SC.

9. D. A. Sharp, "The PWR Steady-State Capability of WRAP - A Water Reactor Analysis Report," NRC Report DPST-NUREG-77-3, June 1977, Savannah River Laboratory, E. I. du Pont de Nemours \& Co., Aiken, SC. 
10. F. Beranek, "User's Guide for the PWR LOCA Analysis Capability of the WRAP-EM System," NRC Report NUREG/CR-1679 (DPSTNUREG-80-2), to be issued in 1980, Savannah River Laboratory, E. I. du Pont de Nemours $\&$ Co., Aiken, SC.

11. C. E. Beyer, et al, "GAPCON-THERMAL-2: A Computer Program for Calculating the Thermal Behavior of an Oxide Fuel Rod, USERDA Reports BNWL-1897 and BNWL-1898, November 1975, Battelle Pacific Northwest Laboratories, Richland, WA.

12. L. J. Siefken, "FRAP-T4 - A Computer Code for the Transient Analysis of Oxide Fuel Rods," USDOE Report CDAP-TR-78-027, July 1978, Idaho National Engineering Laboratory, EG\&G Idaho, Inc., Idaho Falls, ID.

13. D. A. Sharp, "The BWR Steady-State Capability of WRAP-EM," NRC Report NUREG/CR-0712 (DPST-NUREG-78-1), December 1978, Savannah River Laboratory, E. I. du Pont de Némours \& Co., Aiken, SC.

14. S. R. Fischer, et a1, "RELAP4/MOD6 - A Computer Program for Transient Thermal-Hydraulic Analysis of Nuclear Reactors and Related Systems," USDOE Report CDAP-TR-003, January 1978. Idaho National Engineering Laboratory, EG\&G Idaho, Inc., Idaho Falls, ID.

15. G. E. McCreery, "RELAP4/MOD5 REFLOOD Heat Transfer Evaluation Model Improvements," USDOE Report GEM-1-79, June 1979, Idaho National Engineering Laboratory, EG\&G Idaho, Inc., Idaho Falls, ID.

16. G. W. Johnson and L. H. Sullivan, "LPWR 'EM' Models for RFLAP4/MOD5," USDOE Report CDAP-TR-78-034, August 1978, Idaho National Engineering Laboratory, EG\&G Idaho, Inc., Idaho Falls, ID.

17. R. R. Beckmeyer, et al, "User's Guide for the BWR LOCA Analysis Capability of the WRAP-EM System," NRC Report DPST-NUREG-78-3, December 1978, Savannah River Laboratory, E. I. du Pont de Nemours \& Co., Aiken, SC.

18. M. Bohn, et al, "The Licensing Audit Calculation (LACE) Models in the FRAP-T4 Code-Description and Developmental Assessment, USDOE Report EGG-CDAP-5144, April 1980, Idaho National Engineering Laboratory, EG\&G Idaho, Inc., Idaho Falls, ID. 
19. J. A. Block and C. J. Crowley, "Hot Wall Experiments in a Simulated Multiloop PWR Geometry," Report TN-202, February 1975, Creare Science and Technology, Hanover, NH.

20. D. M. Kiser, "The INEL Version of Subroutine LPSURF," USDOE Report DMK-3-79, December 1979, Idaho National Engineering Laboratory, EG\&G Idaho, Inc., Idaho Falls, ID.

21. Interoffice Correspondence from H. Chow to S. R. Behling, "RELAP4-FLOOD to FRAP-T4-LACE Link," Correspondence No.

CHOW-3-79, dated September 13, 1979, EG\&G Idaho, Inc., Idaho Falls, ID.

22. Interoffice Correspondence from L. I. Siefken to T. Howe, "FRAP-T4-LACE Calculations of LOFT L2-5 and Zion LOCA," Correspondence No. L-JS-9-79, dated December 31, 1979, EG\&G Idaho, Inc., Idaho Falls, ID. 


\section{RECEIVED BY. TIC JAN 51981}

\section{$8 \exists \wedge 00$ แ7เ-10yวIW}

